\title{
Synthesis of Some Novel Nanosized Chelates of Anchoring Bisazo Dye 5-[5-(4,6-Dioxo-2-thioxo-hexahydro-pyrimidin-5-ylazo)- naphthalen-1-ylazo]-2-mercapto-1H-pyrimidine-4,6-dione and Their Applications as Antioxidant and Antitumor Agents
}

\author{
Fatma I. Abouzayed,* Saeyda A. Abouel-Enein, and Amira M. Hammad
}

Cite This: ACS Omega 2021, 6, 27737-27754

Read Online

ABSTRACT: A novel bisazo 5-[5-(4,6-dioxo-2-thioxo-hexahydro-pyrimidin-5ylazo)-naphthalen-1-ylazo]-2-mercapto- $1 H$-pyrimidine-4,6-dione $\left(\mathrm{H}_{4} \mathrm{~L}\right)$ ligand has been synthesized from diazotization coupling between naphthalene-1,5diamine and 2-thiobarbituric acid. $\mathrm{Mn}(\mathrm{II}), \mathrm{Co}(\mathrm{II}), \mathrm{Ni}(\mathrm{II}), \mathrm{Cu}(\mathrm{II}), \mathrm{Zn}(\mathrm{II})$, and $\mathrm{Fe}$ (III) chelates were prepared. All prepared compounds were characterized by different techniques. The azo groups did not participate in chelation according to the infrared spectra, whereas the thioamide group did participate. The azo dye ligand coordinated with all metallic ions in a neutral-keto-thiol structure and behaved as a bi- and tridentate moiety. Zinc, manganese, and iron chelates had an octahedral structure, while nickel and cobalt chelates had a tetrahedral structure, but the copper chelate had a square pyramidal geometry. The thermal behavior of all prepared compounds was investigated and thermokinetic parameters were also discussed. X-ray diffraction (XRD) data reflected that $\mathrm{Fe}(\mathrm{III})$ and $\mathrm{Zn}$ (II)

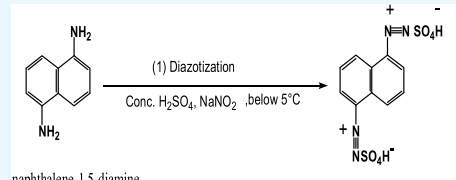
naphthalene-1,5-diamine

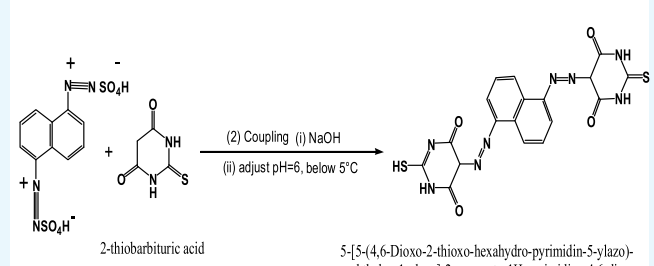
5-[3-44,6-Dioxo-2-thioxo-hexahydro-pyrimidint-5-ylazo)-
naphthalen-1-ylazo-2-mercapto-1H-pyrimidine-4, 6 -dione complexes were crystalline while the $\mathrm{Cu}(\mathrm{II})$ complex was amorphous. Calcination of the $\mathrm{Fe}(\mathrm{III})$ complex at $600{ }^{\circ} \mathrm{C}$ yielded a nanosized $\mathrm{Fe}_{2} \mathrm{O}_{3}$ crystalline phase, elucidated by XRD and transmission electron microscope. The novel azo dye and some of its chelates were tested against HepG-2. The $\mathrm{Fe}_{2} \mathrm{O}_{3}$ nanooxide showed remarkable activity against the HepG-2 cell line rather than its precursor Fe(III) complex. $\mathrm{Co}$ (II) had a higher antioxidant activity than the other investigated complexes. In both activities, the $\mathrm{Cu}$ (II) complex did not show any activity. Molecular modeling and some theoretical studies were validated, and the experimental results were interpreted.

\section{INTRODUCTION}

Azo chromophores are a class of materials distinguished by the presence of an azo or more than one azo group, such as two groups (disazo), three (trisazo), or, more rarely, four (tetrakisazo) and more (polyazo). ${ }^{1}$ Azo compounds have been utilized in the chemical industry as colors, food additives, initiators, indicators, and medicinal agents. ${ }^{2,3}$

Among these azo compounds, bisazo dyes, which are a wellknown class of commercial dyes, occupy more than half of the dye chemistry. The bisazo reactive dyes are more valuable and potentially more economic than monoazo dyes due to their high stability. ${ }^{4,5}$ Bisazo dyes have versatile applications in different fields and play a vital role as ligands in coordination chemistry and have fostered the chemists to construct a large number of homo-/hetero binuclear or polynuclear metal complexes. ${ }^{6}$

Thiobarbituric acid (TBA) is a pyrimidine-thiol compound. Its active hydrogen atom at $\mathrm{C}-5$ is highly acidic, so it can be coupled with diazonium salts of any amine in a basic medium, yielding a high number of colored azo dye derivatives. ${ }^{7}$ These azo dye derivatives have peculiar applications as hypnotic drugs, anticancer, and virucide and have profound antimicrobial and anti-inflammatory activity. ${ }^{8,9}$ Moreover, they are multifunctional ligands and can be chelated with different metal ions to design azo dye metal complexes with potentially modified biological effects. ${ }^{10}$ Chelation theory explained this enhancement and returned it to the effect of metal ions. ${ }^{11}$

Furthermore, the metal chelates were used as a precursor in the thermal preparation of nanosized metal oxides. Metal oxide nanoparticles are applicable in different fields due to their small size, high surface area, adsorptive characteristics, surface defects, fast diffusion, high magnetic properties, less poisonous, and microwave absorption characteristics. ${ }^{12,13}$ Because of this, they are important in catalysis, magnetic storage media, biosensors, and water treatment. ${ }^{14}$ They have extensive

Received: June 7, 2021

Published: October 15, 2021

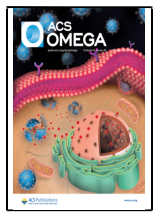


Table 1. Physical and Analytical Results of All Compounds

\begin{tabular}{|c|c|c|c|c|c|c|c|c|}
\hline \multirow[b]{2}{*}{ no. } & \multirow[b]{2}{*}{ compound/empirical formula } & \multirow[b]{2}{*}{ color/formula weight } & \multicolumn{5}{|c|}{ found/(calc.) \% } & \multirow[b]{2}{*}{$\Lambda^{a}$} \\
\hline & & & $\mathrm{C}$ & $\mathrm{H}$ & $\mathrm{N}$ & $\mathrm{M}$ & $\mathrm{X}$ & \\
\hline \multirow{4}{*}{1} & $\mathrm{H}_{4} \mathrm{~L} \cdot \mathrm{H}_{2} \mathrm{O} \cdot 1.25 \mathrm{EtOH}$ & reddish brown & 45.61 & 3.78 & 20.39 & - & - & - \\
\hline & $\mathrm{C}_{20.5} \mathrm{H}_{21.5} \mathrm{~N}_{8} \mathrm{O}_{6.25} \mathrm{~S}_{2}$ & 543.91 & $(45.26)$ & $(3.98)$ & $(20.60)$ & - & - & \\
\hline & {$\left[\mathrm{Mn}_{2}\left(\mathrm{H}_{4} \mathrm{~L}\right) \mathrm{Cl}_{2}(\mathrm{OH})_{2}\left(\mathrm{H}_{2} \mathrm{O}\right)_{2}\right] \cdot 8.5 \mathrm{H}_{2} \mathrm{O}$} & brown & 24.92 & 3.91 & 12.79 & 12.55 & 8.28 & 23 \\
\hline & $\mathrm{C}_{18} \mathrm{H}_{35} \mathrm{~N}_{8} \mathrm{O}_{16.5} \mathrm{~S}_{2} \mathrm{Mn}_{2} \mathrm{Cl}_{2}$ & 872.21 & $(24.78)$ & $(4.04)$ & $(12.84)$ & $(12.59)$ & $(8.12)$ & \\
\hline \multirow[t]{2}{*}{2} & {$\left[\mathrm{Co}_{2}\left(\mathrm{H}_{4} \mathrm{~L}\right) \mathrm{Cl}_{2}(\mathrm{OH})_{2}\right] \cdot 8.5 \mathrm{H}_{2} \mathrm{O} \cdot 2 \mathrm{EtOH}$} & brown & 28.59 & 4.48 & 12.53 & 13.10 & 7.50 & 21 \\
\hline & $\mathrm{C}_{22} \mathrm{H}_{43} \mathrm{~N}_{8} \mathrm{O}_{16.5} \mathrm{~S}_{2} \mathrm{Co}_{2} \mathrm{Cl}_{2}$ & 919.27 & $(28.74)$ & $(4.71)$ & $(12.18)$ & $(12.83)$ & $(7.71)$ & \\
\hline \multirow[t]{2}{*}{3} & {$\left[\mathrm{Ni}_{2}\left(\mathrm{H}_{4} \mathrm{~L}\right) \mathrm{Cl}_{2}(\mathrm{OH})_{2}\right] \cdot 7.5 \mathrm{H}_{2} \mathrm{O} \cdot 0.5 \mathrm{EtOH}$} & brown & 26.65 & 3.71 & 13.47 & 13.77 & 8.51 & 17 \\
\hline & $\mathrm{C}_{19} \mathrm{H}_{32} \mathrm{~N}_{8} \mathrm{O}_{14} \mathrm{~S}_{2} \mathrm{Ni}_{2} \mathrm{Cl}_{2}$ & 848.74 & $(26.88)$ & $(3.79)$ & $(13.20)$ & $(13.82)$ & $(8.35)$ & \\
\hline \multirow[t]{2}{*}{4} & {$\left[\mathrm{Cu}_{2}\left(\mathrm{H}_{4} \mathrm{~L}\right) \mathrm{Cl}_{2}(\mathrm{OH})_{2}\right] \cdot \mathrm{H}_{2} \mathrm{O} \cdot 5.5 \mathrm{EtOH}$} & black & 35.51 & 4.87 & 11.24 & 12.77 & 7.34 & 28 \\
\hline & $\mathrm{C}_{29} \mathrm{H}_{49} \mathrm{~N}_{8} \mathrm{O}_{12.5} \mathrm{~S}_{2} \mathrm{Cu}_{2} \mathrm{Cl}_{2}$ & 971.58 & $(35.84)$ & $(5.07)$ & $(11.53)$ & $(13.07)$ & $(7.29)$ & \\
\hline \multirow[t]{2}{*}{5} & {$\left[\mathrm{Zn}_{2}\left(\mathrm{H}_{4} \mathrm{~L}\right) \mathrm{Cl}_{2}(\mathrm{OH})_{2}\left(\mathrm{H}_{2} \mathrm{O}\right)_{4}\right] \cdot 4 \mathrm{H}_{2} \mathrm{O} \cdot 1.5 \mathrm{EtOH}$} & gray & 27.42 & 4.56 & 12.58 & 13.92 & 7.93 & 15 \\
\hline & $\mathrm{C}_{21} \mathrm{H}_{39} \mathrm{~N}_{8} \mathrm{O}_{15.5} \mathrm{~S}_{2} \mathrm{Zn}_{2} \mathrm{Cl}_{2}$ & 917.72 & $(27.48)$ & $(4.27)$ & $(12.20)$ & $(14.24)$ & $(7.72)$ & \\
\hline \multirow[t]{2}{*}{6} & {$\left[\mathrm{Fe}_{2}\left(\mathrm{H}_{4} \mathrm{~L}\right) \mathrm{Cl}_{4}(\mathrm{OH})_{2}\left(\mathrm{H}_{2} \mathrm{O}\right)_{2}\right] \cdot 6.5 \mathrm{H}_{2} \mathrm{O} \cdot 0.5 \mathrm{EtOH}$} & black & 24.38 & 3.39 & 12.39 & 11.72 & 15.11 & 23 \\
\hline & $\mathrm{C}_{19} \mathrm{H}_{34} \mathrm{~N}_{8} \mathrm{O}_{15} \mathrm{~S}_{2} \mathrm{Fe}_{2} \mathrm{Cl}_{4}$ & 931.91 & $(24.48)$ & $(3.67)$ & $(12.02)$ & (11.98) & $(15.21)$ & \\
\hline
\end{tabular}

\section{Scheme 1. Mass Degradation of the $\left(\mathrm{H}_{4} \mathrm{~L}\right)$ Azo Dye Ligand}
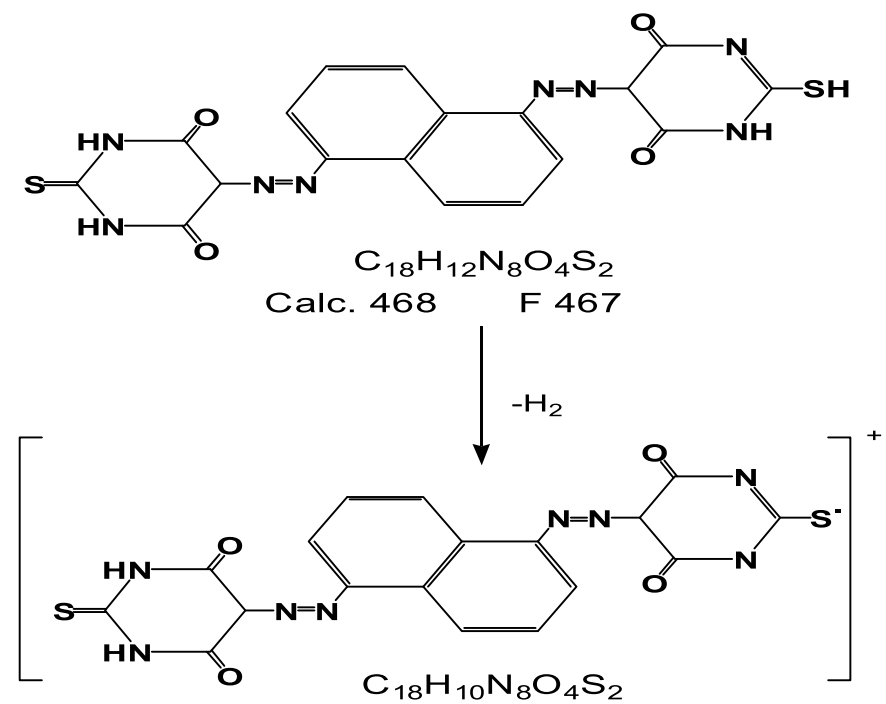

Calc. $466 \quad$ F 465

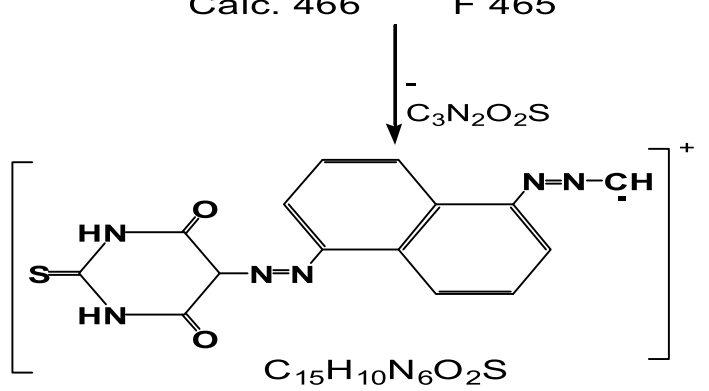

Calc. $338 \quad$ F 339

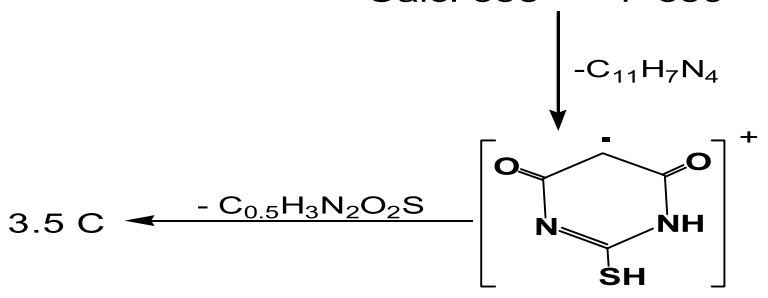

Calc. $42 \quad F 42$

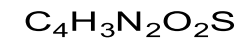

Calc. 143 F 144 


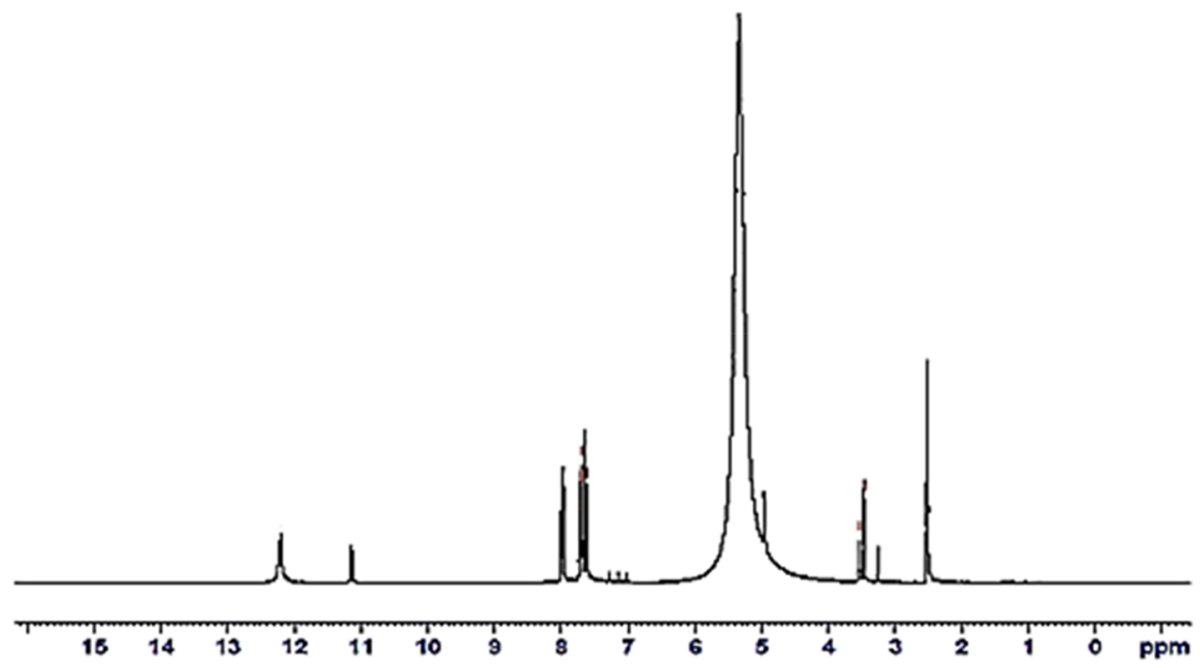

Figure 1. ${ }^{1} \mathrm{H}$ NMR spectra of the $\left(\mathrm{H}_{4} \mathrm{~L}\right)$ ligand.

biomedical applications such as anticancer, antimicrobial, and mosquitocidal and are used in repairing tissue, biological fluid detoxification, immunoassay, and cell separation. ${ }^{15}$

The studies on naphthalene-1,5-diamine azo dye derivatives and bisazo dyes are rather rare, so in this research, naphthalene-1,5-diamine was used as an amine moiety in a diazotization reaction with TBA (phenol moiety) to form a novel bisazo dye. The chelating manner of the synthesized organic ligand toward different metallic ions [such as $\mathrm{Mn}$ (II), $\mathrm{Co}(\mathrm{II}), \mathrm{Ni}(\mathrm{II}), \mathrm{Cu}(\mathrm{II}), \mathrm{Zn}(\mathrm{II})$, and $\mathrm{Fe}(\mathrm{III})]$ was studied. All prepared compounds were investigated by a variety of analytical, thermal, and spectral tools to establish their proposed structure. Also, they were tested as antitumor agents against HepG-2 cells and antioxidants. Furthermore, we used the prepared nanosized $\mathrm{Fe}$ (III) complex as a precursor for the preparation of $\mathrm{Fe}_{2} \mathrm{O}_{3}$ and tested its cytotoxic activity. Some theoretical studies were done and correlated with experimental data.

\section{RESULTS AND DISCUSSION}

2.1. Analytical Data. 2.1.1. Structure Elucidation of All Prepared Compounds. Different colored complexes with a 2 M:1 L stoichiometry were isolated when the 5-[5-(4,6-dioxo-2thioxo-hexahydro-pyrimidin-5-ylazo)-naphthalen-1-ylazo]-2mercapto- $1 \mathrm{H}$-pyrimidine-4,6-dione $\left(\mathbf{H}_{4} \mathbf{L}\right)$ ligand reacted with $\mathrm{Mn}(\mathrm{II}), \mathrm{Co}(\mathrm{II}), \mathrm{Ni}(\mathrm{II}), \mathrm{Cu}(\mathrm{II}), \mathrm{Zn}(\mathrm{II})$, and $\mathrm{Fe}(\mathrm{III})$ chloride salts. The analytical data (Table 1) demonstrated a binuclear structure for all complexes. All prepared compounds were stable for a long time at room temperature, partially soluble in chloroform, methanol, ethanol, and acetonitrile, and highly soluble in dimethyl sulfoxide (DMSO) and dimethylformamide (DMF). The nonelectrolytic character of the complexes was ensured by the low conductance values $\left(15-28 \Omega^{-1} \mathrm{~cm}^{2}\right.$ $\mathrm{mol}^{-1}$ ) (Table 1), showing that the anions were in the coordinated sphere of the metal ion. ${ }^{16}$

2.2. Spectral Studies. 2.2.1. Mass Spectra. Scheme 1 depicts the FAB fragmentations of the ligand based on the mass spectrum. The spectrum revealed a molecular ion peak at $m / z=467 \mathrm{amu}$ corresponding to the parent molecular weight of the ligand, confirming the expected molecular weight without solvent. This proved the ligand's monomeric structure. ${ }^{17}$ Also, the spectrum demonstrated various peaks at $m / z=465,339,144$, and 42 corresponding to
$\left[\mathrm{C}_{18} \mathrm{H}_{10} \mathrm{~N}_{8} \mathrm{O}_{4} \mathrm{~S}_{2}\right]^{+}, \quad\left[\mathrm{C}_{15} \mathrm{H}_{10} \mathrm{~N}_{6} \mathrm{O}_{2} \mathrm{~S}\right]^{+}, \quad\left[\mathrm{C}_{4} \mathrm{H}_{3} \mathrm{~N}_{2} \mathrm{O}_{2} \mathrm{~S}\right]^{+}$, and 3.5C, respectively.

The molecular ion peak at $m / z 756 \mathrm{amu}$ in the mas spectrum of $\left[\mathrm{Co}_{2}\left(\mathrm{H}_{4} \mathrm{~L}\right) \mathrm{Cl}_{2}(\mathrm{OH})_{2}\right] \cdot 8.5 \mathrm{H}_{2} \mathrm{O} \cdot 2 \mathrm{EtOH}$ $\left(\mathrm{C}_{22} \mathrm{H}_{43} \mathrm{~N}_{8} \mathrm{O}_{16.5} \mathrm{~S}_{2} \mathrm{Co}_{2} \mathrm{Cl}_{2}\right)$ was consistent with a calculated molecular weight of $755 \mathrm{~g} / \mathrm{mol}$, which was the molecular weight of the complex after the loss of four molecules of hydrated water and two molecules of ethanol. Moreover, the spectrum gave multiple peaks, including those at $m / z 673,639$, and $601 \mathrm{amu}$, which were attributed to the formula of $\mathrm{C}_{18} \mathrm{H}_{14} \mathrm{~N}_{8} \mathrm{O}_{6} \mathrm{~S}_{2} \mathrm{Co}_{2} \mathrm{Cl}_{2}, \mathrm{C}_{18} \mathrm{H}_{14} \mathrm{~N}_{8} \mathrm{O}_{6} \mathrm{~S}_{2} \mathrm{Co}_{2} \mathrm{Cl}$, and $\mathrm{C}_{18} \mathrm{H}_{14} \mathrm{~N}_{8} \mathrm{O}_{6} \mathrm{~S}_{2} \mathrm{Co}_{2}$ due to the consecutive loss of $4.5 \mathrm{~mol}$ of crystallized water, coordinated chloride, and coordinated chloride, respectively. The mass spectrum of $\left[\mathrm{Zn}_{2}\left(\mathrm{H}_{4} \mathrm{~L}\right)\right.$ $\left.\mathrm{Cl}_{2}(\mathrm{OH})_{2}\left(\mathrm{H}_{2} \mathrm{O}\right)_{4}\right] \cdot 4 \mathrm{H}_{2} \mathrm{O} \cdot 1.5 \mathrm{EtOH} \quad\left(\mathrm{C}_{21} \mathrm{H}_{39} \mathrm{~N}_{8} \mathrm{O}_{15.5} \mathrm{~S}_{2} \mathrm{Zn}_{2} \mathrm{Cl}_{2}\right)$ reflected a peak at $m / z 804 \mathrm{amu}$, which corresponded to the molecular weight of $803 \mathrm{~g} / \mathrm{mol}$, which was of the complex after the loss of 2.5 molecules of hydrated water and 1.5 molecules of ethanol. Moreover, other peaks arose as a result of fragmentations caused by the breakdown of bonds inside the complex. A molecular ion peak at $m / z 665 \mathrm{amu}$, compatible with $664 \mathrm{~g} / \mathrm{mol}$, was found in the mass spectrum of $\left[\mathrm{Cu}_{2}\left(\mathrm{H}_{4} \mathrm{~L}\right) \mathrm{Cl}_{2}(\mathrm{O} \mathrm{H})_{2}\right] \cdot \mathrm{H}_{2} \mathrm{O} \cdot 5.5 \mathrm{Et} \mathrm{OH}$ $\left(\mathrm{C}_{29} \mathrm{H}_{49} \mathrm{~N}_{8} \mathrm{O}_{12.5} \mathrm{~S}_{2} \mathrm{Cu}_{2} \mathrm{Cl}_{2}\right)$, pointed to $\mathrm{C}_{18} \mathrm{H}_{14} \mathrm{~N}_{8} \mathrm{O}_{6} \mathrm{~S}_{2} \mathrm{Cu}_{2} \mathrm{Cl}$. The peaks at $m / z 648,631$, and 595 were assigned to $\mathrm{C}_{18} \mathrm{H}_{13} \mathrm{~N}_{8} \mathrm{O}_{5} \mathrm{~S}_{2} \mathrm{Cu}_{2} \mathrm{Cl}, \mathrm{C}_{18} \mathrm{H}_{12} \mathrm{~N}_{8} \mathrm{O}_{4} \mathrm{~S}_{2} \mathrm{Cu}_{2} \mathrm{Cl}$, and $\mathrm{C}_{18} \mathrm{H}_{12} \mathrm{~N}_{8} \mathrm{O}_{4} \mathrm{~S}_{2} \mathrm{Cu}_{2}$ formulas, respectively.

2.2.2. ${ }^{1} \mathrm{H} N M R$ Spectra. Figure 1 represents the ligand's ${ }^{1} \mathrm{H}$ NMR spectrum. It revealed triplet signals at 7.62-7.99 ppm, corresponding to six protons of the naphthalene ring (based on the integration value, $1 \mathrm{H}=0.76) .{ }^{18}$ Also, the spectrum showed two singlet signals at 11.14 and $12.20 \mathrm{ppm}$, representing three protons of the amidic $(\mathrm{NH})$ group ${ }^{19,20}$ and an acidic proton of the $(\mathrm{SH})$ group at $3.53 \mathrm{ppm} .{ }^{21}$ The appearance of $\mathrm{NH}$ protons in a 3:1 ratio with $\mathrm{SH}$ proton and the absence of $\mathrm{OH}$ protons are indicative of the keto-thione-thiol structure of the ligand. $^{22}$ The $\left(\mathrm{C}_{5}-\mathrm{H}\right)$ of TBA was detected by two signals at 3.47 and $3.25 \mathrm{ppm}^{23}$ The low integral value of $\left(\mathrm{C}_{5}-\mathrm{H}\right)$ protons may be due to some interaction with the solvent. ${ }^{24}$ The broad strong signal at $5.33 \mathrm{ppm}$ was assignable to the solvent of crystallization. ${ }^{25}$

2.2.3. Infrared Spectra. The infrared spectrum of the prepared azo dye displayed spectral bands at (1708; 1672), 
529, and $456 \mathrm{~cm}^{-1}$ due to the stretching and bending vibrations of $(\mathrm{C}=\mathrm{O}),(\mathrm{C}-\mathrm{C}=\mathrm{O})$, and $(\mathrm{C}=\mathrm{O})$, respectively (Table 2). ${ }^{26,27}$ The $(\mathrm{SH})$ group was characterized by the

Table 2. Most Characteristic Infrared Spectral Bands $\left(\mathrm{cm}^{-1}\right)$ and Their Assignments of the $\left(\mathrm{H}_{4} \mathrm{~L}\right)$ Ligand

\begin{tabular}{|c|c|c|c|}
\hline bands & assignment & bands & assignment \\
\hline 3451 & $\begin{array}{l}v_{\text {as }}(\mathrm{OH}) \\
\text { solvent }\end{array}$ & 1421,1411 & $v(\mathrm{~N}=\mathrm{N})$ \\
\hline 3094 & $v_{s}(\mathrm{NH})$ & 1178,1064 & $\begin{array}{l}v(\mathrm{C}-\mathrm{N})+v(\mathrm{C}=\mathrm{S})+\mathrm{CH} \text { in- } \\
\text { plane bending }\end{array}$ \\
\hline 3037 & $v(\mathrm{C}-\mathrm{H})_{\mathrm{Arm}}$ & 1008 & ring vibration \\
\hline 2824 & $v\left(\mathrm{C}_{5}-\mathrm{H}\right)_{\mathrm{TBA}}$ & 788 & $\gamma(\mathrm{NH})$ \\
\hline 2594 & $v(\mathrm{~S}-\mathrm{H})$ & 720 & $v(\mathrm{C}=\mathrm{S})$ \\
\hline $\begin{array}{l}1708, \\
1672\end{array}$ & $v(\mathrm{C}=\mathrm{O})$ & 625 & $v[(\mathrm{C}-\mathrm{S})+(\mathrm{N}-\mathrm{C}=\mathrm{O})]$ \\
\hline \multirow[t]{2}{*}{1639} & $v(\mathrm{C}=\mathrm{N})$ & 580 & $v(\mathrm{~N}-\mathrm{C}=\mathrm{O})+\mathrm{SH}$ deformation \\
\hline & & 529 & $v(\mathrm{C}-\mathrm{C}=\mathrm{O})$ \\
\hline 1520 & $\delta(\mathrm{NH})$ & 456 & $\gamma(\mathrm{C}=\mathrm{O})$ \\
\hline
\end{tabular}

observed band at $2594 \mathrm{~cm}^{-1}$ attributed to $v(\mathrm{SH}),{ }^{28}$ additional bands at 625 and $580 \mathrm{~cm}^{-1}$ due to overlapped bands of $v[(\mathrm{C}-$ $\mathrm{S})+(\mathrm{N}-\mathrm{C}=\mathrm{O})]$ and $[v(\mathrm{~N}-\mathrm{C}=\mathrm{O})+(\mathrm{SH}$ deformation $)]$, respectively. ${ }^{28-30}$ However, the $720 \mathrm{~cm}^{-1}$ band was assigned to $v(\mathrm{C}=\mathrm{S})^{31}$ with other bands at 1178 and $1064 \mathrm{~cm}^{-1}$ characterized to $v(\mathrm{C}-\mathrm{N})+v(\mathrm{C}=\mathrm{S}) .{ }^{32}$ The spectrum also gave a band at $1639 \mathrm{~cm}^{-1}$ attributed to $v(\mathrm{C}=\mathrm{N})$ group of the thiobarbituric moiety. ${ }^{33}$ The observed bands at 3094, 1520, and $788 \mathrm{~cm}^{-1}$ were attributable to $\nu, \delta$, and $\gamma$ of the amidic $\mathrm{NH}$ group, respectively. ${ }^{34}$

The azo group was assigned by the appearance of bands at 1422 and $1411 \mathrm{~cm}^{-1}$ due to $v(\mathrm{~N}=\mathrm{N}) .^{35}$ The band at 2824 $\mathrm{cm}^{-1}$ attributed to $v\left(\mathrm{C}_{5}-\mathrm{H}\right)_{\text {TBA }}$ implied that the ligand had an azo structure but not a hydrazo structure. ${ }^{34}$ According to the foregoing assignments, the ligand was found in the ketothiol-thione form.

The ligand's bonding manner toward different metallic ions is based on the careful comparison of the ligand's IR spectrum with that of its chelates. The most characteristic spectral bands and their assignments are tabulated in Table 3, and the infrared spectra are graphically shown in Figure 2. The data reflected some key points in the following

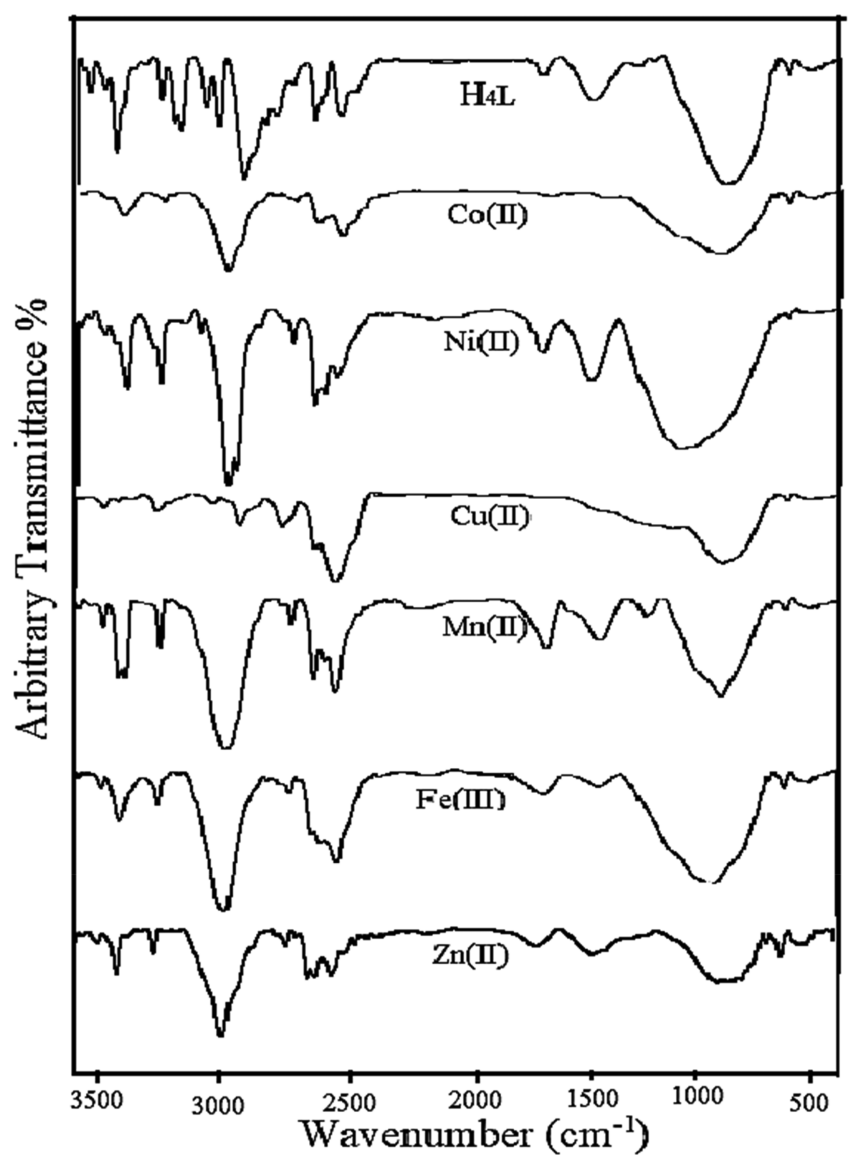

Figure 2. Infrared spectra of all synthesized compounds.

1 Two carbonyl groups in weak and shoulder nature were found in all complexes. The first one was in the 1718$1735 \mathrm{~cm}^{-1}$ range, with a shift of $27-10 \mathrm{~cm}^{-1}$ in comparison to the free ligand. However, the second carbonyl group exerted change by different degrees. In $\mathrm{Ni}$ (II) and $\mathrm{Cu}$ (II) complexes, it disappeared, while in the other complexes, it shifted to a higher value by $16-7$ $\mathrm{cm}^{-1}$. Meanwhile, $v(\mathrm{~N}-\mathrm{C}=\mathrm{O})$ showed a significant effect. This behavior of the vibration of $(\mathrm{C}=\mathrm{O})$ group

Table 3. Infrared Spectral Bands $\left(\mathrm{cm}^{-1}\right)$ and Their Assignments for All Synthesized Compounds

\begin{tabular}{|c|c|c|c|c|c|c|c|}
\hline \multicolumn{8}{|c|}{ compounds/bands } \\
\hline assignment & $\mathrm{H} 4 \mathrm{~L}$ & $\mathrm{Mn}(\mathrm{II})$ & $\mathrm{Co}(\mathrm{II})$ & $\mathrm{Ni}(\mathrm{II})$ & $\mathrm{Cu}(\mathrm{II})$ & $\mathrm{Zn}(\mathrm{II})$ & $\mathrm{Fe}(\mathrm{III})$ \\
\hline$v(\mathrm{OH})$ & 3451 & 3446 & 3453 & 3469 & 3449 & 3449 & 3417 \\
\hline$v(\mathrm{NH})$ & 3094 & 3140 & 3015 & 3156 & 3077 & 3140 & - \\
\hline$v(\mathrm{C}-\mathrm{H})_{\mathrm{TBA}}$ & 2824 & 2869 & 2844 & 2821 & 2952 & 2857 & 2873 \\
\hline$v(\mathrm{~S}-\mathrm{H})$ & 2594 & 2621 & 2623 & 2594 & 2546 & 2596 & 2613 \\
\hline$v(\mathrm{C}=\mathrm{S})$ & 720 & - & - & - & - & - & - \\
\hline$v(\mathrm{C}=\mathrm{O})$ & 1708,1672 & 1735,1687 & 1733,1697 & $1718,-$ & $1718,-$ & 1734,1679 & 1735,1688 \\
\hline$v(\mathrm{C}=\mathrm{N})$ & 1639 & 1623 & 1642 & 1620 & 1616 & 1626 & 1638 \\
\hline$\delta(\mathrm{NH})$ & 1520 & 1530 & 1536 & 1521 & 1528 & 1559 & 1524 \\
\hline$\gamma(\mathrm{NH})$ & 788 & 798 & 797 & 787 & 767 & 792 & 795 \\
\hline$v(\mathrm{~N}=\mathrm{N})$ & 1421,1411 & 1421 & 1422 & 1418 & 1400 & 1418 & 1418 \\
\hline$v(\mathrm{C}-\mathrm{N})+v(\mathrm{C}-\mathrm{O})+v(\mathrm{M}-\mathrm{OH})$ & 1178,1064 & 1104 & 1156,1098 & 1142,1104 & 1165,1048 & 1187,1112 & 1106 \\
\hline$v(\mathrm{~N}-\mathrm{C}=\mathrm{O})$ & 580 & 580 & 609 & 578 & 598 & 619 & 618 \\
\hline$v(\mathrm{C}-\mathrm{C}=\mathrm{O})$ & 529 & 529 & 540 & 531 & 530 & 530 & 534 \\
\hline$\gamma(\mathrm{C}=\mathrm{O})+v(\mathrm{M}-\mathrm{O})$ & 456 & 456 & 437 & 484 & 437 & 438 & 469 \\
\hline$v(\mathrm{M}-\mathrm{N})+v(\mathrm{M}-\mathrm{S})$ & - & 406 & 422 & 422 & 422 & 421 & 422 \\
\hline
\end{tabular}


Table 4. Electronic Spectral Results and Magnetic Moment Values

\begin{tabular}{|c|c|c|c|c|}
\hline no. & compound & spectral bands (nm) & assignment & $\mu_{\text {eff: }} /$ metal ion \\
\hline & $\mathrm{H}_{4} \mathrm{~L} \cdot 1.25 \mathrm{EtOH}$ & 212,295 & $\pi-\pi^{*}$ & \\
\hline & & 464 & $\mathrm{n}-\pi^{*}$ & \\
\hline \multirow[t]{3}{*}{1} & {$\left[\mathrm{Mn}_{2}\left(\mathrm{H}_{4} \mathrm{~L}\right) \mathrm{Cl}_{2}(\mathrm{OH})_{2}\left(\mathrm{H}_{2} \mathrm{O}\right)_{2}\right] \cdot 8.5 \mathrm{H}_{2} \mathrm{O}$} & $220,301,468$ & intraligand transition & 4.15 \\
\hline & & 470 & $\mathrm{LMCT}+{ }^{6} \mathrm{~A}_{1 \mathrm{~g}} \rightarrow{ }^{4} \mathrm{~T}_{2 \mathrm{~g}}\left({ }^{4} \mathrm{G}\right)$ & \\
\hline & & 672 & ${ }^{6} \mathrm{~A}_{1 \mathrm{~g}} \rightarrow{ }^{4} \mathrm{~T}_{1 \mathrm{~g}}\left({ }^{4} \mathrm{G}\right)$ & \\
\hline \multirow[t]{3}{*}{2} & {$\left[\mathrm{Co}_{2}\left(\mathrm{H}_{4} \mathrm{~L}\right) \mathrm{Cl}_{2}(\mathrm{OH})_{2}\right] \cdot 8.5 \mathrm{H}_{2} \mathrm{O} \cdot 2 \mathrm{EtOH}$} & $215,277,468$ & intraligand transition & 4.17 \\
\hline & & 508 & LMCT & \\
\hline & & 712 & ${ }^{4} \mathrm{~A}_{2} \rightarrow{ }^{4} \mathrm{~T}_{1 \mathrm{P}}$ & \\
\hline \multirow[t]{4}{*}{3} & {$\left[\mathrm{Ni}_{2}(\mathrm{H} 4 \mathrm{~L}) \mathrm{Cl}_{2}(\mathrm{OH})_{2}\right] \cdot 7.5 \mathrm{H}_{2} \mathrm{O} \cdot 0.5 \mathrm{EtOH}$} & $221,289,471$ & intraligand transition & 3.48 \\
\hline & & 510 & LMCT & \\
\hline & & 668 & ${ }^{3} \mathrm{~T}_{1} \rightarrow{ }^{3} \mathrm{~T}_{2}$ & \\
\hline & & 868 & ${ }^{3} \mathrm{~T}_{1} \rightarrow{ }^{3} \mathrm{~T}_{1}(\mathrm{p})$ & \\
\hline \multirow[t]{4}{*}{4} & {$\left[\mathrm{Cu}_{2}\left(\mathrm{H}_{4} \mathrm{~L}\right) \mathrm{Cl}_{2}(\mathrm{OH})_{2}\right] \cdot \mathrm{H}_{2} \mathrm{O} .5 \cdot 5 \mathrm{EtOH}$} & $218,286,450$ & Intraligand transition & 1.05 \\
\hline & & 513 & $\mathrm{LMCT}+{ }^{2} \mathrm{~B}_{1 \mathrm{~g}} \rightarrow{ }^{2} \mathrm{E}_{\mathrm{g}}$ & \\
\hline & & 669 & ${ }^{2} \mathrm{~B}_{1 \mathrm{~g}} \rightarrow{ }^{2} \mathrm{~B}_{2 \mathrm{~g}}$ & \\
\hline & & 915 & ${ }^{2} \mathrm{~B}_{1 \mathrm{~g}} \rightarrow{ }^{2} \mathrm{~A}_{1 \mathrm{~g}}$ & \\
\hline \multirow[t]{5}{*}{5} & {$\left[\mathrm{Fe}_{2}\left(\mathrm{H}_{4} \mathrm{~L}\right) \mathrm{Cl}_{4}(\mathrm{OH})_{2}\left(\mathrm{H}_{2} \mathrm{O}\right)_{2}\right] \cdot 6.5 \mathrm{H}_{2} \mathrm{O} \cdot 0.5 \mathrm{EtOH}$} & $217,284,470$ & intraligand transition & 5.19 \\
\hline & & 506 & LMCT & \\
\hline & & 606 & ${ }^{6} \mathrm{~A}_{1 \mathrm{~g}}(\mathrm{~S}) \rightarrow{ }^{4} \mathrm{~A}_{1 \mathrm{~g}}\left({ }^{4} \mathrm{G}\right)$ & \\
\hline & & 663 & ${ }^{4} \mathrm{~A}_{1 \mathrm{~g}}(\mathrm{~S}) \rightarrow{ }^{4} \mathrm{~T}_{2 \mathrm{~g}}\left({ }^{4} \mathrm{G}\right)$ & \\
\hline & & 718 & ${ }^{6} \mathrm{~A}_{1 \mathrm{~g}}(\mathrm{~S}) \rightarrow{ }^{4} \mathrm{~T}_{2 \mathrm{~g}}\left({ }^{4} \mathrm{G}\right)$ & \\
\hline \multirow[t]{2}{*}{6} & {$\left[\mathrm{Zn}_{2}\left(\mathrm{H}_{4} \mathrm{~L}\right) \mathrm{Cl}_{2}(\mathrm{OH})_{2}\left(\mathrm{H}_{2} \mathrm{O}\right)_{4}\right] \cdot 4 \mathrm{H}_{2} \mathrm{O} .1 \cdot 5 \mathrm{EtOH}$} & $218,277,469$ & intraligand transition & \\
\hline & & 490 & LMCT & \\
\hline
\end{tabular}

during chelation indicates the contribution of the carbonyl group's oxygen atom in chelation. ${ }^{36}$ The $\gamma(\mathrm{C}=\mathrm{O})$ was observed in the $437-484 \mathrm{~cm}^{-1}$ range upon complexation, typified $v(\mathrm{M}-\mathrm{O}){ }^{37}$

2 Except for $\mathrm{Ni}$ (II) and $\mathrm{Zn}$ (II) complexes, all complexes showed a strong shift in $v(\mathrm{SH})$ and $\mathrm{SH}$-deformation in plane at 2594 and $580 \mathrm{~cm}^{-1}$. In addition, in all complexes, the $v(\mathrm{C}=\mathrm{S})$ band at $720 \mathrm{~cm}^{-1}$ disappeared, confirming the thiol structure. Meanwhile, thioamide III was not detected in complexes ${ }^{38}$ because its band was overlapped with $[v(\mathrm{C}-\mathrm{N})+v(\mathrm{C}-\mathrm{O})+(\mathrm{CH}$-out-ofplane)] and associated with the appearance of a new band in the range of $1048-1112 \mathrm{~cm}^{-1}$ characterized to $v(\mathrm{M}-\mathrm{OH}) .^{38-48}$

3 In all complexes except $\mathrm{Co}(\mathrm{II})$ and $\mathrm{Fe}(\mathrm{III}), v(\mathrm{C}=\mathrm{N})$ of the pyrimidine ring at $1639 \mathrm{~cm}^{-1}$ was strongly shifted by $13-23 \mathrm{~cm}^{-1}$, indicating that the nitrogen atom of the imine group was a chelation site for all metal ions except $\mathrm{Co}(\mathrm{II})$ and $\mathrm{Fe}(\mathrm{III})$ ions. $^{27,41}$ The azo group at 1411 and $1422 \mathrm{~cm}^{-1}$ appeared as one band upon complexation at $1418-1422 \mathrm{~cm}^{-1}$, with a slight effect showing that the azo group's nitrogen atom did not contribute to coordination. ${ }^{42}$

4 All modes of vibration of the $(\mathrm{NH})$ group $(v, \delta$, and $\gamma)$ showed a slight change in all complexes due to intra-/ interhydrogen bonding. The presence of coordinated water in $\mathrm{Mn}$ (II), $\mathrm{Zn}$ (II), and $\mathrm{Fe}$ (III) was confirmed by medium bands at $828-890 \mathrm{~cm}^{-1}$, characteristic $v(\mathrm{M} \leftarrow$ $\mathrm{OH}_{2}$ ), and these bands were not observed in the spectra of the other metal complexes. ${ }^{43} \mathrm{New}$ bands at 406-422 $\mathrm{cm}^{-1}$ were assignable to $v(\mathrm{M}-\mathrm{N})$ overlapped with $v(\mathrm{M}-\mathrm{S}) .{ }^{44,45}$ The $(\mathrm{M}-\mathrm{S})$ band was not purely detected due to the hard-soft interaction behavior. ${ }^{46}$

According to the preceding justifications, the ligand was in a neutral keto thiol form and exerted various manners of bonding with each metallic ion. It was chelated in the OS bidentate fashion with $\mathrm{Co}$ (II) and $\mathrm{Fe}$ (III) ions, ON bidentate fashion with $\mathrm{Zn}(\mathrm{II})$ and $\mathrm{Ni}(\mathrm{II})$ ions, and ONS tridentate moiety with $\mathrm{Mn}$ (II) and $\mathrm{Cu}$ (II) ions.

2.2.4. Electronic Absorption Spectra and Magnetic Moment Measurements. The azo dye ligand and its chelates were examined in the ultraviolet-visible range, and the results are compiled in Table 4 . The intraligand $\pi-\pi^{*}$ transition of heterocyclic and aromatic rings was assignable at the shortest wavelengths of 212 and $295 \mathrm{~nm} .^{34,47}$ The band at $\lambda_{\max }=464$ $\mathrm{nm}$ was caused by the ligand's conjugated system $\mathrm{n}-\pi^{*}$ transition. ${ }^{48}$ The electronic spectra of metal chelates showed bands at 215-221, 277-301, and 450-470 $\mathrm{nm}$ assignable to $\pi-\pi^{*}$ and $n-\pi^{*}$ transitions, which exhibited notable shifts relative to the native ligand. The shifts established coordination. $^{49}$ It was explained that once the metal ion was coordinated to the ligand's donor atoms, it was easier to supply an unbonded electron to the $\pi$-electron system, causing a shift in the absorption of the azo dye ligand. This was dependent on the type of metallic ion. ${ }^{50}$ Extra bands in the $470-513$ and 470-915 $\mathrm{nm}$ ranges were seen in the spectra of complexes, which were attributed to LMCT and $\mathrm{d}-\mathrm{d}$ transitions, respectively.

The electronic spectrum of the $\mathrm{Mn}$ (II) complex revealed bands at 470 and $672 \mathrm{~nm}$, assigned to ${ }^{6} \mathrm{~A}_{1 \mathrm{~g}} \rightarrow{ }^{4} \mathrm{~T}_{2 \mathrm{~g}}\left({ }^{4} \mathrm{G}\right)$ and ${ }^{6} \mathrm{~A}_{1 \mathrm{~g}} \rightarrow{ }^{4} \mathrm{~T}_{1 \mathrm{~g}}\left({ }^{4} \mathrm{G}\right)$ transitions that were fairly close to an octahedral structure. At room temperature, the magnetic moment value was found to be 4.15 B.M, which agreed well with the distorted octahedral geometry around the $\mathrm{Mn}$ (II) ion. $^{27,51}$ The Co(II) complex exhibited one absorption band at $712 \mathrm{~nm}$, which was attributed to ${ }^{4} \mathrm{~A}_{2} \rightarrow{ }^{4} \mathrm{~T}_{1 \mathrm{P}}$ transition. The magnetic measurements indicated that the complex had a paramagnetic character with a magnetic moment of 4.17 B.M, suggesting a tetrahedral geometry. ${ }^{52}$

In accordance with a tetrahedral structure, $\mathrm{Ni}(\mathrm{II})$ complex absorption spectral bands at 668 and $868 \mathrm{~cm}^{-1}$ were attributed 
to ${ }^{3} \mathrm{~T}_{1} \rightarrow{ }^{3} \mathrm{~T}_{2}$ and ${ }^{3} \mathrm{~T}_{1} \rightarrow{ }^{3} \mathrm{~T}_{1}(\mathrm{p})$ transitions, respectively. It had a magnetic moment value of $3.48 \mathrm{BM}$ that was reported for the tetrahedral structure. ${ }^{52}$ Bands at 513, 669, and $915 \mathrm{~nm}$ in the $\mathrm{Cu}(\mathrm{II})$ complex described ${ }^{2} \mathrm{~B}_{1 \mathrm{~g}} \rightarrow{ }^{2} \mathrm{E}_{\mathrm{g}},{ }^{2} \mathrm{~B}_{1 \mathrm{~g}} \rightarrow{ }^{2} \mathrm{~B}_{2 \mathrm{~g}}$, and ${ }^{2} \mathrm{~B}_{1 \mathrm{~g}} \rightarrow$ ${ }^{2} \mathrm{~A}_{1 \mathrm{~g}}$ transitions, referring to the square pyramidal geometry. ${ }^{52,53}$ The calculated $\mu_{\text {eff }}$ value for the $\mathrm{Cu}$ (II) complex was 1.05 B.M. ${ }^{54}$ The absorption bands of the $\mathrm{Fe}$ (III) chelate appeared at 606, 663, and $718 \mathrm{~nm}$ and were assigned to ${ }^{6} \mathrm{~A}_{1 \mathrm{~g}}(\mathrm{~S}) \rightarrow{ }^{4} \mathrm{~A}_{1 \mathrm{~g}},{ }^{4} \mathrm{E}_{\mathrm{g}}\left({ }^{4} \mathrm{G}\right)$ and ${ }^{4} \mathrm{~A}_{1 \mathrm{~g}}(\mathrm{~S}) \rightarrow{ }^{4} \mathrm{~T}_{2 \mathrm{~g}}\left({ }^{4} \mathrm{G}\right)$, and ${ }^{6} \mathrm{~A}_{1 \mathrm{~g}}(\mathrm{~S})$ $\rightarrow{ }^{4} \mathrm{~T}_{2 \mathrm{~g}}\left({ }^{4} \mathrm{G}\right)$ transitions, respectively. This implied $\mathrm{Fe}(\mathrm{III})$ octahedral geometry with $\mathrm{d}^{2} \mathrm{sp}^{3}$ hybridization, which was emphasized by the $\mu_{\text {eff }}$ value of 5.19 B.M. ${ }^{55}$ The electronic spectrum of the diamagnetic $\mathrm{Zn}$ (II) complex exhibited a band at $490 \mathrm{~nm}$, which was due to charge transfer, while the $\mathrm{d}-\mathrm{d}$ transition was impossible. Based on its analytical, conductance, and spectral results, the octahedral structure was postulated. ${ }^{56}$ The low magnetic moment values for all complexes were due to the antiferromagnetic interaction between the two metallic centers in binuclear complexes. ${ }^{57}$

The above discussion (elemental and spectral investigations) suggested the metal chelate structure, as shown in Figure 3.

2.3. Thermal Studies. The thermal properties of all prepared compounds were investigated by thermogravimetry and derivative thermogravimetry (TG/DTG). It was done to

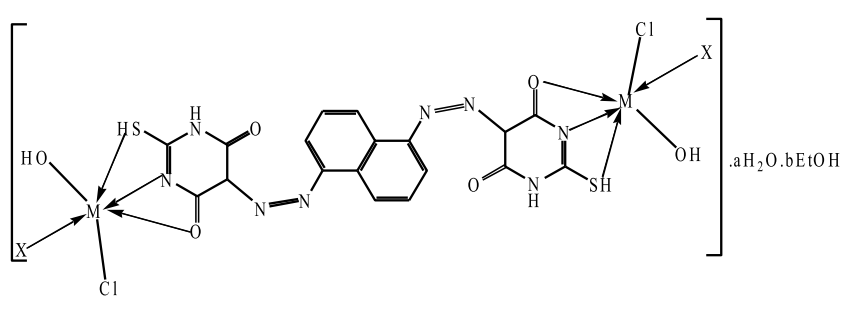

\begin{tabular}{lccc}
\hline Complex & $\mathrm{X}$ & $\mathrm{a}$ & $\mathrm{b}$ \\
\hline $\mathrm{Mn}(\mathrm{II})$ & $\mathrm{H}_{2} \mathrm{O}$ & 8.5 & - \\
$\mathrm{Cu}(\mathrm{II})$ & - & 1 & 5.5
\end{tabular}
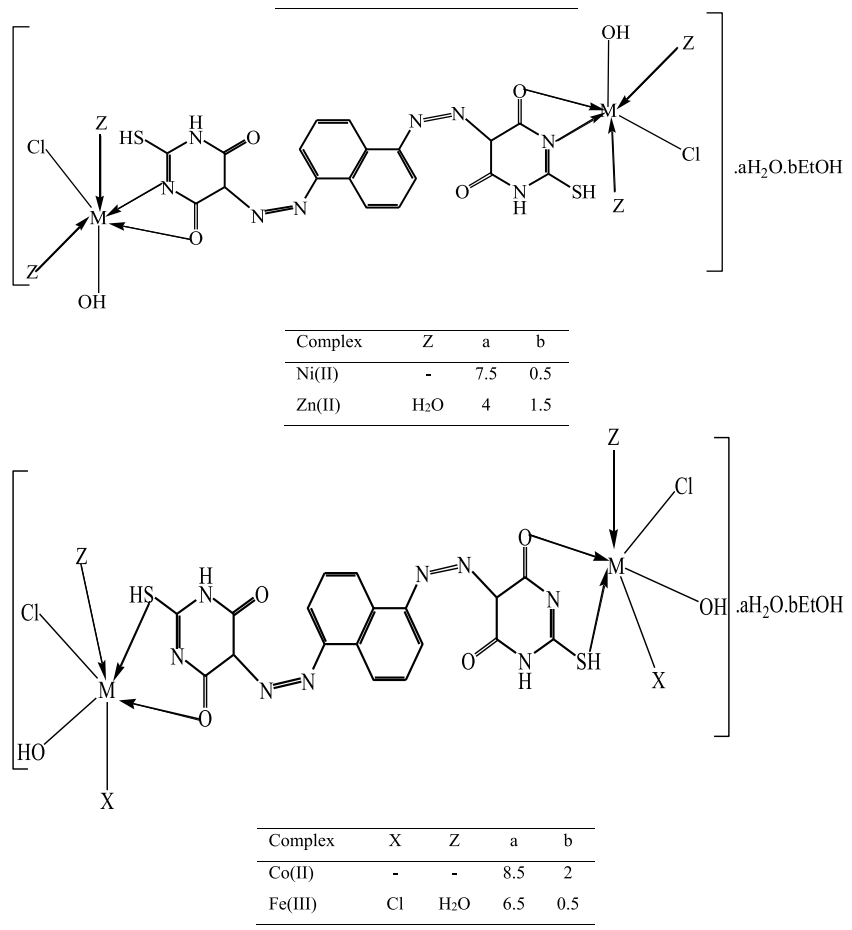

Figure 3. Postulated chemical structure of metal complexes. emphasize the complex structure, determine the thermal stability, and specify the different kinds of solvents. The thermoanalytical data are summarized in Table 5. The thermograms of all investigated compounds are demonstrated in Figure 4. The DTG curves of the ligand and its metal chelates were examined by the following rate equation ${ }^{58}$

$$
\frac{\mathrm{d} \alpha}{\mathrm{d} t}=K(1-\alpha)^{n}
$$

where $n$ and $\alpha$ are the reaction order and the decomposed fraction, respectively. $K$ is the rate constant which is calculated by the Arrhenius equation: $K=A \mathrm{e}^{-E_{*} /(R T)}$, where $A, E^{*}, R$, and $T$ are the frequency factor, activation energy, molar gas constant, and temperature (kelvin), respectively. The PiloyanNovikova method was applied for the determination of these parameters, ${ }^{59}$ in which the natural logarithm of the intensity of the DTG peak $(\ln I)$ is plotted against $1000 / T$. The activation energy is calculated from the slope of the straight line. However, the kinetic parameters for the synthesized compounds $\left(\Delta H, \Delta S^{*}, \Delta G^{*}, h\right.$, and $\left.K\right)$ were estimated using the following equations ${ }^{60}$ and are recorded in Table 6.

$$
\begin{gathered}
\Delta H=\Delta E^{*}-R T ; \quad \Delta S^{*}=R T \ln (A h / K T) ; \\
\Delta G^{*}=\Delta H-T \Delta S^{*}
\end{gathered}
$$

The ligand's TG pattern suggested that the thermal breakdown process occurred in two stages. The first process involved total dehydration and desolvation in the $27-220{ }^{\circ} \mathrm{C}$ range with a weight loss of $13.44 \%$. This process had an activation energy of $22.41 \mathrm{~kJ} \mathrm{~mol}^{-1}$ via a first-order reaction. Afterward, the organic compound underwent pyrolysis, which was marked by a $85.66 \%$ TG weight loss in the temperature range of $220-800{ }^{\circ} \mathrm{C}$ with DTG peaks at $T_{\max }=227,302$, and $562{ }^{\circ} \mathrm{C}$. The decomposition process occurred completely without leaving any residue, and the calculated and found weight losses were consistent, proving that the loss of the ligand occurred as gases at the specified temperature range. This confirmed our suggested ligand molecular weight. ${ }^{61}$

The thermograms of $\left[\mathrm{Zn}_{2}\left(\mathrm{H}_{4} \mathrm{~L}\right) \mathrm{Cl}_{2}(\mathrm{OH})_{2}\left(\mathrm{H}_{2} \mathrm{O}\right)_{4}\right] \cdot 4 \mathrm{H}_{2} \mathrm{O}$. $1.5 \mathrm{EtOH}$ and $\left[\mathrm{Fe}_{2}\left(\mathrm{H}_{4} \mathrm{~L}\right) \mathrm{Cl}_{4}(\mathrm{OH})_{2}\left(\mathrm{H}_{2} \mathrm{O}\right)_{2}\right] \cdot 6.5 \mathrm{H}_{2} \mathrm{O} \cdot 0.5 \mathrm{EtOH}$ complexes denoted that they were decomposed by nearly similar pathways but were not isothermal. The thermal breakdown of the chelates was accomplished in three clear steps. The TG curves displayed a weight loss at $27-267{ }^{\circ} \mathrm{C}$, which might be attributed to the total elimination of the crystallization solvent with DTG peaks at $T_{\max }=146$ and 74 ${ }^{\circ} \mathrm{C}$ for $\mathrm{Zn}$ (II) and $\mathrm{Fe}$ (III) complexes, respectively. The low onset temperature and a broad range of releasing the solvent of crystallization indicate that these solvents were included in the voids but not in the lattice structure. ${ }^{62}$ After that, $\mathrm{Zn}$ (II) and $\mathrm{Fe}$ (III) complexes revealed weight losses of 19.17 and $39.05 \%$ within $262-399$ and $267-407{ }^{\circ} \mathrm{C}$ ranges, with DTG peaks at $T_{\max }=313$ and $345{ }^{\circ} \mathrm{C}$, respectively. It represented the elimination of coordinated water, hydroxyl group, and chloride ions (Table 5) as well as partial ligand pyrolysis of the Fe(III) complex. The last decomposition process was achieved up to $800{ }^{\circ} \mathrm{C}$ and characterized by weight losses of 40.72 and $24.96 \%$ assignable to complete ligand pyrolysis, leaving metal oxides $\left(2 \mathrm{ZnO}+4.5 \mathrm{C}\right.$ and $\left.\mathrm{Fe}_{2} \mathrm{O}_{3}+3 \mathrm{C}\right)$ as the final products. ${ }^{63,64}$ The last decomposition step was accompanied by a broad DTG peak at $T_{\max }=588$ and $621{ }^{\circ} \mathrm{C}$ for $\mathrm{Zn}$ (II) and $\mathrm{Fe}$ (III) chelates, respectively. The $\mathrm{Fe}_{2} \mathrm{O}_{3}$ product was characterized by X-ray diffraction (XRD) and transmission electron microscopy 
Table 5. Thermoanalytical Data of the Ligand and Its Chelates ${ }^{a}$

\begin{tabular}{|c|c|c|c|c|c|c|c|}
\hline \multirow[b]{2}{*}{ no. } & \multirow[b]{2}{*}{ compound } & \multirow[b]{2}{*}{$\begin{array}{l}\text { TG range } \\
\left({ }^{\circ} \mathrm{C}\right)\end{array}$} & \multirow[b]{2}{*}{ DTG $\left({ }^{\circ} \mathrm{C}\right)$} & \multicolumn{2}{|c|}{ mass loss $\%$} & \multirow[b]{2}{*}{ Characterization } & \multirow[b]{2}{*}{$\begin{array}{c}T_{\mathrm{S}} \\
\left({ }^{\circ} \mathrm{C}\right)\end{array}$} \\
\hline & & & & found & calc. & & \\
\hline & $\mathrm{H}_{4} \mathrm{~L} \cdot \mathrm{H}_{2} \mathrm{O} \cdot 1.25 \mathrm{EtOH}$ & $27-220$ & 68 & 13.44 & 13.89 & $\left(\mathrm{~mol} \mathrm{H} \mathrm{H}_{2} \mathrm{O}+1.25 \mathrm{~mol} \mathrm{EtOH}\right)^{\mathrm{a}+\mathrm{b}}$ & 220 \\
\hline & & $220-800$ & $227,302,562$ & 85.66 & 85.86 & complete ligand pyrolysis $^{\mathrm{d}}$ & \\
\hline & & at 800 & - & - & - & no residue & \\
\hline \multirow[t]{5}{*}{1} & {$\left[\mathrm{Mn}_{2}\right.$} & $29-236$ & 56,188 & 9.27 & 9.29 & $\left(4.5 \mathrm{~mol} \mathrm{H}_{2} \mathrm{O}\right)^{\mathrm{a}}$ & 236 \\
\hline & & $236-340$ & 322 & 12.97 & 12.39 & $\left(4 \mathrm{~mol} \mathrm{H}_{2} \mathrm{O}_{\text {(lattice) }}+2 \mathrm{~mol} \mathrm{H}_{2} \mathrm{O}_{\text {(coord. })}\right)^{\mathrm{a}+\mathrm{d}}$ & \\
\hline & & $340-577$ & 516 & 46.35 & 45.75 & $\left(2 \mathrm{~mol} \mathrm{OH}+\mathrm{mol} \mathrm{Cl}{ }_{2}+\mathrm{C}_{7.5} \mathrm{H}_{12} \mathrm{~N}_{8} \mathrm{OS}_{2}\right)^{\mathrm{d}}$ & \\
\hline & & $577-800$ & - & 3.86 & 4.13 & $(\mathrm{~mol} \mathrm{C})$ & \\
\hline & & at 800 & - & 28.38 & 28.39 & $\mathrm{Mn}_{2} \mathrm{O}_{3}+7.5 \mathrm{C}^{\mathrm{r}}$ & \\
\hline \multirow[t]{3}{*}{2} & {$\left[\mathrm{Co}_{2}\left(\mathrm{H}_{4} \mathrm{~L}\right) \mathrm{Cl}_{2}(\mathrm{OH})_{2}\right]$} & $27-288$ & 99 & 25.28 & 26.67 & $\left(8.5 \mathrm{~mol} \mathrm{H}_{2} \mathrm{O}+2 \mathrm{~mol} \mathrm{EtOH}\right)^{\mathrm{a}+\mathrm{b}}$ & 288 \\
\hline & & $288-795$ & $331,471,771$ & 29.20 & 30.99 & $\left(2 \mathrm{~mol} \mathrm{OH}+\mathrm{mol} \mathrm{Cl}_{2}+\mathrm{C}_{10} \mathrm{H}_{4} \mathrm{~N}_{4}\right)^{\mathrm{d}}$ & \\
\hline & & at 795 & - & 45.17 & 44.18 & $\mathrm{Co}_{2} \mathrm{O}_{3}+$ organic part ${ }^{\mathrm{r}}$ & \\
\hline \multirow[t]{4}{*}{3} & {$\left[\mathrm{Ni}_{2}\left(\mathrm{H}_{4} \mathrm{~L}\right) \mathrm{Cl}_{2}(\mathrm{OH})_{2}\right]$} & $29-235$ & 110,225 & 19.47 & 18.62 & $\left(7.5 \mathrm{~mol} \mathrm{H}_{2} \mathrm{O}+0.5 \mathrm{~mol} \mathrm{EtOH}\right)^{\mathrm{a}+\mathrm{b}}$ & 235 \\
\hline & & $235-344$ & - & 12.19 & 12.36 & $\left(2 \mathrm{~mol} \mathrm{OH}+\mathrm{mol} \mathrm{Cl}_{2}\right)^{\mathrm{d}}$ & \\
\hline & & $344-800$ & $348,513,727$ & 45.33 & 45.74 & $\left(\mathrm{C}_{14} \mathrm{H}_{12} \mathrm{~N}_{8} \mathrm{O}_{2} \mathrm{~S}_{2}\right)^{\mathrm{d}}$ & \\
\hline & & at 800 & - & 23.16 & 22.94 & $2 \mathrm{NiO}+4 \mathrm{C}^{\mathrm{r}}$ & \\
\hline \multirow[t]{3}{*}{4} & {$\left[\mathrm{Cu}_{2}\left(\mathrm{H}_{4} \mathrm{~L}\right) \mathrm{Cl}_{2}(\mathrm{OH})_{2}\right] \cdot \mathrm{H}_{2} \mathrm{O}$} & $26-260$ & 75 & 23.48 & 23.70 & $(5 \mathrm{~mol} \mathrm{EtOH})^{\mathrm{b}}$ & 260 \\
\hline & & $260-760$ & 277,357 & 60.60 & 59.92 & $\left(0.5 \mathrm{~mol} \mathrm{EtOH}+\mathrm{mol} \mathrm{H}_{2} \mathrm{O}+2 \mathrm{~mol} \mathrm{OH}+\mathrm{mol} \mathrm{Cl}_{2}+\mathrm{C}_{18} \mathrm{H}_{12} \mathrm{~N}_{8} \mathrm{O}_{2} \mathrm{~S}_{2}\right)^{\mathrm{a}+\mathrm{b}+\mathrm{d}}$ & \\
\hline & & at 760 & & 15.99 & 16.36 & $2 \mathrm{CuO}^{\mathrm{r}}$ & \\
\hline \multirow[t]{4}{*}{5} & $\begin{array}{l}{\left[\mathrm{Zn}_{2}\left(\mathrm{H}_{4} \mathrm{~L}\right) \mathrm{Cl}_{2}(\mathrm{OH})_{2}\left(\mathrm{H}_{2} \mathrm{O}\right)_{4}\right.} \\
\quad] \cdot 4 \mathrm{H}_{2} \mathrm{O} \cdot 1.5 \mathrm{EtOH}\end{array}$ & $27-262$ & 146 & 16.14 & 15.37 & $\left(4 \mathrm{~mol} \mathrm{H}_{2} \mathrm{O}+1.5 \mathrm{~mol} \mathrm{EtOH}\right)^{\mathrm{a}+\mathrm{b}}$ & 262 \\
\hline & & $262-399$ & 313 & 19.17 & 19.28 & $\left(4 \mathrm{~mol} \mathrm{H}{ }_{2} \mathrm{O}+2 \mathrm{~mol} \mathrm{OH}+\mathrm{mol} \mathrm{Cl}_{2}\right)^{\mathrm{d}}$ & \\
\hline & & $399-800$ & 588 & 40.72 & 41.64 & $\left(\mathrm{C}_{13.5} \mathrm{H}_{12} \mathrm{~N}_{8} \mathrm{O}_{2} \mathrm{~S}_{2}\right)^{\mathrm{d}}$ & \\
\hline & & at 800 & - & 22.86 & 23.31 & $2 \mathrm{ZnO}+4.5 \mathrm{C}^{\mathrm{r}}$ & \\
\hline \multirow[t]{4}{*}{6} & {$\left[\mathrm{Fe}_{2}\left(\mathrm{H}_{4} \mathrm{~L}\right) \mathrm{Cl}_{4}(\mathrm{OH})_{2}\left(\mathrm{H}_{2} \mathrm{O}\right)_{2}\right.$} & $27-267$ & 74 & 15.24 & 15.03 & $\left(6.5 \mathrm{~mol} \mathrm{H}_{2} \mathrm{O}+0.5 \mathrm{~mol} \mathrm{EtOH}\right)^{\mathrm{a}+\mathrm{b}}$ & 267 \\
\hline & & $267-407$ & 345 & 39.05 & 39.35 & $\left(2 \mathrm{~mol} \mathrm{H}{ }_{2} \mathrm{O}+2 \mathrm{~mol} \mathrm{OH}+2 \mathrm{~mol} \mathrm{Cl}_{2}+\mathrm{C}_{4} \mathrm{H}_{3} \mathrm{~N}_{4} \mathrm{OS}\right)^{\mathrm{d}}$ & \\
\hline & & $407-800$ & 621 & 24.96 & 24.59 & $\left(\mathrm{C}_{11} \mathrm{H}_{9} \mathrm{~N}_{4} \mathrm{~S}\right)^{\mathrm{d}}$ & \\
\hline & & at 800 & - & 20.55 & 20.79 & $\mathrm{Fe}_{2} \mathrm{O}_{3}+3 \mathrm{C}^{\mathrm{r}}$ & \\
\hline
\end{tabular}

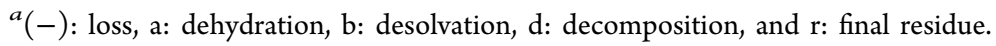

(TEM). Scheme 2 depicts the thermal decomposition mechanism for binuclear complexes.

The $\left[\mathrm{Mn}_{2}\left(\mathrm{H}_{4} \mathrm{~L}\right) \mathrm{Cl}_{2}(\mathrm{OH})_{2}\left(\mathrm{H}_{2} \mathrm{O}\right)_{2}\right] \cdot 8.5 \mathrm{H}_{2} \mathrm{O}$ thermogram reflected $9.27 \%$ weight loss in the temperature range of 236-29 ${ }^{\circ} \mathrm{C}$ with DTG peaks at $T_{\max }=56$ and $188{ }^{\circ} \mathrm{C}$, indicating partial dehydration. The pyrolysis of the inner sphere of the complex occurred via two main steps. The first pyrolytic one started with the elimination of coordinated water and the rest of lattice water molecules up to $340{ }^{\circ} \mathrm{C}$, as evidenced by $12.97 \%$ weight loss with the DTG peak at $T_{\max }=$ $322{ }^{\circ} \mathrm{C}$. The second was declared weight loss of $46.35 \%$ equivalent to the loss of coordinated anions as well as partially ligand pyrolysis within the temperature range of $340-577{ }^{\circ} \mathrm{C}$. The TG curve displayed a weight loss of $3 \mathrm{~mol}$ carbon (up to $800{ }^{\circ} \mathrm{C}$ ), resulting in $\mathrm{Mn}_{2} \mathrm{O}_{3}$ mixed with carbon as a final product. ${ }^{65}$ The thermal pyrolytic mechanism is illustrated in Scheme 3.

$\left[\mathrm{Ni}_{2}\left(\mathrm{H}_{4} \mathrm{~L}\right) \mathrm{Cl}_{2}(\mathrm{OH})_{2}\right] \cdot 7.5 \mathrm{H}_{2} \mathrm{O} \cdot 0.5 \mathrm{EtOH}, \quad\left[\mathrm{Cu}_{2}\left(\mathrm{H}_{4} \mathrm{~L}\right)-\right.$ $\left.\mathrm{Cl}_{2}(\mathrm{OH})_{2}\right] \cdot \mathrm{H}_{2} \mathrm{O} \cdot 5.5 \mathrm{EtOH}$, and $\left[\mathrm{Co}_{2}\left(\mathrm{H}_{4} \mathrm{~L}\right) \mathrm{Cl}_{2}(\mathrm{OH})_{2}\right]$. $8.5 \mathrm{H}_{2} \mathrm{O} \cdot 2 \mathrm{EtOH}$ complexes were nearly decomposed by similar pathways. TG curves showed weight loss of 19.47 and $25.28 \%$ at $29-235$ and $27-288{ }^{\circ} \mathrm{C}$, corresponding to complete removal of solvent of crystallization. The complexes started decomposition at 235 and $288{ }^{\circ} \mathrm{C}$, respectively. The first decomposition step occurred with an estimated weight loss of 12.19 and $29.20 \%$, which was indicative of the removal of coordinated anions in addition to partial ligand pyrolysis in the case of $\mathrm{Co}(\mathrm{II})$ complex. The second step in the range 344$795{ }^{\circ} \mathrm{C}$ associated with TG weight loss of $45.33 \%$ for $\mathrm{Ni}(\mathrm{II})$ complex due to the pyrolysis of the rest of the ligand, and the residual product was in agreement with $2 \mathrm{NiO} .{ }^{66}$ However, the thermal decomposition process of $\mathrm{Co}$ (II) complex was ended with the formation of $\mathrm{Co}_{2} \mathrm{O}_{3}$ with organic part as a final residue. While the thermogram of $\left[\mathrm{Cu}_{2}\left(\mathrm{H}_{4} \mathrm{~L}\right) \mathrm{Cl}_{2}(\mathrm{OH})_{2}\right]$. $\mathrm{H}_{2} \mathrm{O} .5 \cdot 5 \mathrm{EtOH}$ complex exhibited weight loss of $23.48 \%$ at $27-260{ }^{\circ} \mathrm{C}$ corresponding to partial desolvation process. The complex started decomposition at $260-760{ }^{\circ} \mathrm{C}$ with weight loss of $60.60 \%$, characterized by loss of the rest of the solvent, all coordinated anions, and pyrolysis of the organic ligand. This step ended with formation of $2 \mathrm{CuO}$ as the final residue. ${ }^{67-, 69}$ The thermal decomposition mechanism for $\mathrm{Ni}(\mathrm{II})$ and $\mathrm{Cu}(\mathrm{II})$ chelates is shown in Scheme 4.

The thermal pyrolysis of all chelates indicated that the ligand had an oxidizing effect. In addition, the chelates exerted higher thermal stability than the uncoordinated ligand. This returned to the chelate structure. ${ }^{70}$ The highest thermal stability was found for the $\mathrm{Co}(\mathrm{II})$ complex, which was due to the high number of solvents that participated in hydrogen bonding with the coordinated anions, resulting in a less flexible but very stable compound. The thermal stability of complexes was also affected by the characteristics of metallic ions. ${ }^{71}$ 

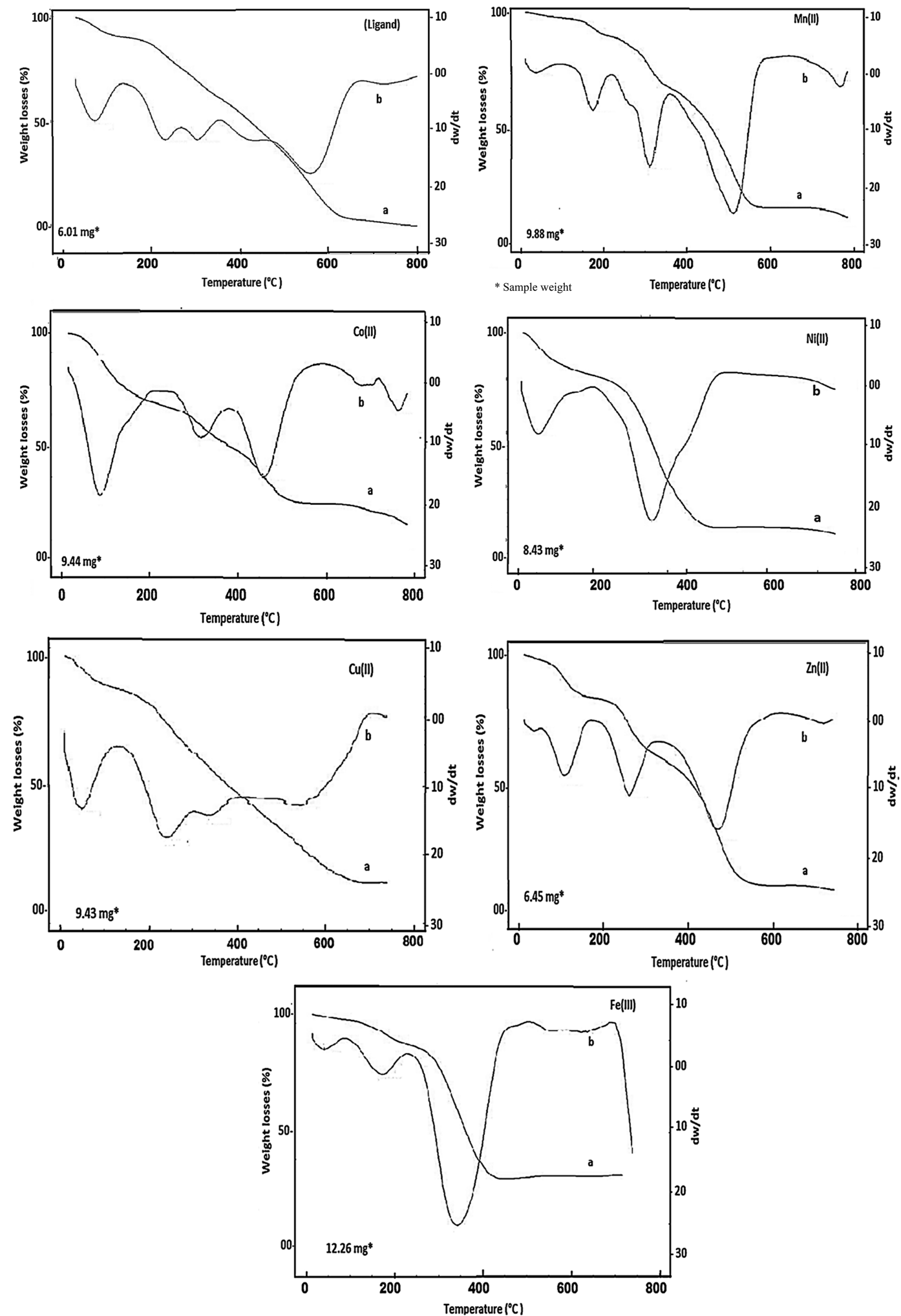

Figure 4. TG/DTG curves of all synthesized compounds: (a) TG and (b) DTG curves.

2.3.1. Kinetic Calculations. The investigation of Tables 5 and 6 established the following:

1 All thermal stages of all compounds obeyed first-order kinetics.

2 Taking the major decomposition stage as a criterion, the increased activation energy values of the decomposition stage in all complexes rather than in the ligand reflected the high stability of complexes, which could be attributed to the chelate structure and the covalent bond character. $^{72}$ The data showed that $\mathrm{Cu}(\mathrm{II})$ was a less thermally stable complex with less decomposition activation energy and also less dehydration/desolvation activation energy. The low activation energy values of 
Table 6. Kinetic and Thermodynamic Parameters of All Compounds

\begin{tabular}{|c|c|c|c|c|c|c|c|c|c|c|}
\hline no. & compound & stage & temperature range & DTG peak & $n$ & $\Delta E^{*}$ & $\Delta H^{*}$ & $A$ & $\Delta S^{*}$ & $\Delta G^{*}$ \\
\hline \multirow{7}{*}{1} & \multirow[t]{3}{*}{$\mathrm{H}_{4} \mathrm{~L} \cdot \mathrm{H}_{2} \mathrm{O} \cdot 1.25 \mathrm{EtOH}$} & I & $27-220$ & 68 & 1.29 & 22.41 & 22.07 & 38.19 & -0.215 & 95.63 \\
\hline & & \multirow[t]{2}{*}{ II } & \multirow[t]{2}{*}{$220-800$} & 227 & 1.16 & 54.17 & 54.11 & 63.13 & -0.214 & 161.48 \\
\hline & & & & 302 & 1.11 & 80.00 & 79.89 & 81.32 & -0.213 & 202.36 \\
\hline & \multirow{4}{*}[\mathrm{Mn}_{2}(\mathrm{H}_{4}\mathrm{L})\mathrm{Cl}_{2}(\mathrm{OH})_{2}(\mathrm{H}_{2}\mathrm{O})_{2}]{$\cdot 8.5 \mathrm{H}_{2} \mathrm{O}$} & \multirow[t]{2}{*}{ I } & \multirow[t]{2}{*}{$29-236$} & 56 & 1.41 & 36.62 & 36.04 & 65.83 & -0.216 & 105.43 \\
\hline & & & & 188 & 1.12 & 65.60 & 65.04 & 83.84 & -0.211 & 162.63 \\
\hline & & II & $236-340$ & 322 & 1.08 & 70.23 & 69.5 & 68.62 & -0.215 & 197.7 \\
\hline & & III & $340-577$ & 516 & 1.31 & 54.58 & 53.11 & 39.68 & -0.222 & 228.26 \\
\hline \multirow[t]{3}{*}{2} & \multirow{3}{*}[\mathrm{Co}_{2}(\mathrm{H}_{4}\mathrm{L})\mathrm{Cl}_{2}(\mathrm{OH})_{2}]{$.8 .5 \mathrm{H}_{2} \mathrm{O} \cdot 2 \mathrm{EtOH}$} & I & $27-288$ & 99 & 1.32 & 23.24 & 22.6 & 36.19 & -0.216 & 103.29 \\
\hline & & II & $288-795$ & 331 & 1.05 & 64.84 & 64.27 & 62.27 & -0.216 & 195.21 \\
\hline & & & & 471 & 1.33 & 60.87 & 60.3 & 47.06 & -0.221 & 224.72 \\
\hline \multirow[t]{5}{*}{3} & \multirow[t]{5}{*}[\mathrm{Ni}_{2}(\mathrm{H}_{4}\mathrm{L})\mathrm{Cl}_{2}(\mathrm{OH})_{2}]{$\cdot 7.5 \mathrm{H}_{2} \mathrm{O} \cdot 0.5 \mathrm{EtOH}$} & \multirow[t]{2}{*}{ I } & \multirow[t]{2}{*}{$29-235$} & 110 & 1.14 & 19.76 & 19.08 & 29.76 & -0.218 & 102.87 \\
\hline & & & & 225 & 1.33 & 24.63 & 24.01 & 28.42 & -0.221 & 134.23 \\
\hline & & \multirow[t]{3}{*}{ III } & \multirow[t]{3}{*}{$344-800$} & 348 & 1.15 & 31.11 & 31.07 & 28.71 & -0.223 & 169.61 \\
\hline & & & & 513 & 1.2 & 26.37 & 25.6 & 19.14 & -0.228 & 205.22 \\
\hline & & & & 727 & 1.22 & 44.24 & 43.38 & 25.24 & -0.228 & 271.5 \\
\hline \multirow[t]{3}{*}{4} & \multirow[t]{3}{*}[\mathrm{Cu}_{2}(\mathrm{H}_{4}\mathrm{L})\mathrm{Cl}_{2}(\mathrm{OH})_{2}]{$\cdot \mathrm{H}_{2} \mathrm{O} \cdot 5.5 \mathrm{EtOH}$} & I & $26-260$ & 75 & 1.34 & 22.25 & 21.85 & 37.11 & -0.216 & 97.05 \\
\hline & & II & $260-760$ & 277 & 1.36 & 32.88 & 32.59 & 34.38 & -0.220 & 153.59 \\
\hline & & & & 375 & 1.17 & 57.26 & 57.09 & 51 & -0.218 & 198.78 \\
\hline \multirow[t]{3}{*}{5} & \multirow{3}{*}[\mathrm{Zn}_{2}(\mathrm{H}_{4}\mathrm{L})\mathrm{Cl}_{2}(\mathrm{OH})_{2}(\mathrm{H}_{2}\mathrm{O})_{4}]{$\cdot 4 \mathrm{H}_{2} \mathrm{O} \cdot 1.5 \mathrm{EtOH}$} & $\mathrm{I}$ & $23-262$ & 146 & 1.32 & 33.1 & 32.08 & 45.88 & -0.215 & 122.55 \\
\hline & & II & $262-399$ & 313 & 1.35 & 57.02 & 56.6 & 56.36 & -0.217 & 183.76 \\
\hline & & & $399-800$ & 588 & 1.07 & 55.70 & 54.07 & 37.06 & -0.223 & 246.66 \\
\hline \multirow[t]{3}{*}{6} & \multirow{3}{*}[\mathrm{Fe}_{2}(\mathrm{H}_{4}\mathrm{L})\mathrm{Cl}_{4}(\mathrm{OH})_{2}(\mathrm{H}_{2}\mathrm{O})_{2}]{$\cdot 6.5 \mathrm{H}_{2} \mathrm{O} \cdot 0.5 \mathrm{EtOH}$} & I & $27-267$ & 74 & 1.13 & 31.04 & 19.84 & 53.07 & -0.213 & 105.00 \\
\hline & & II & $267-407$ & 345 & 1.04 & 50.96 & 50.32 & 47.57 & -0.218 & 185.57 \\
\hline & & III & $407-800$ & 621 & 1.21 & 65.03 & 63.25 & 41.70 & -0.223 & 262.61 \\
\hline
\end{tabular}

Scheme 2. Thermal Decomposition Pathway of $\mathrm{Zn}(\mathrm{II})$ and $\mathrm{Fe}(\mathrm{III})$ Chelates

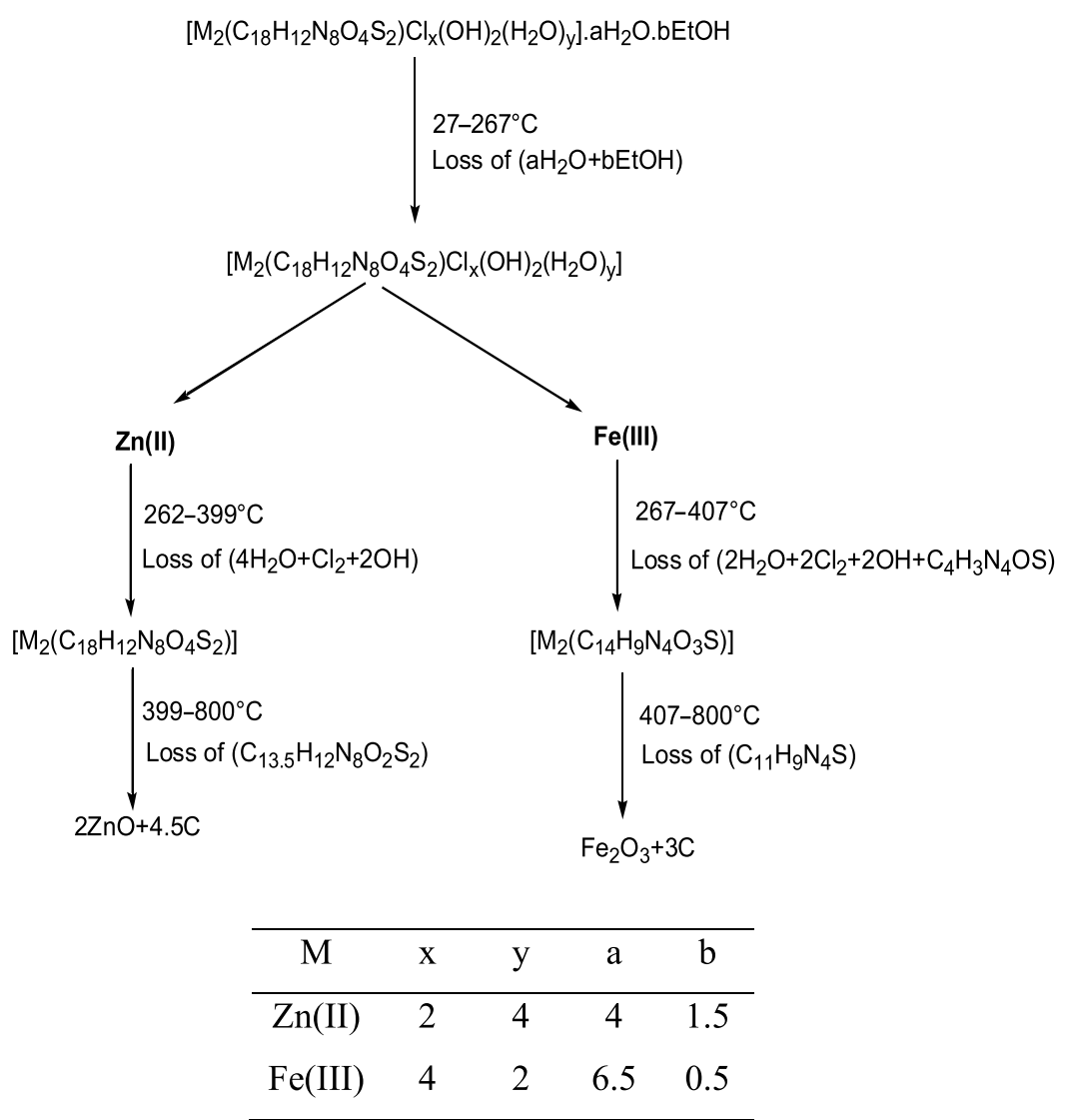

complexes were due to the autocatalytic action of the metal ion on the pyrolytic process. ${ }^{73}$
3 The $\Delta G^{*}$ positive values for the investigated complexes demonstrated that the free energy of the final residue was larger than that of the initial compound and all 
Scheme 3. Thermal Pyrolytic Pathway of the Mn(II) Complex

$$
\begin{aligned}
& {\left[\mathrm{Mn}_{2}\left(\mathrm{C}_{18} \mathrm{H}_{12} \mathrm{~N}_{8} \mathrm{O}_{4} \mathrm{~S}_{2}\right) \mathrm{Cl}_{2}(\mathrm{OH})_{2}\left(\mathrm{H}_{2} \mathrm{O}\right)_{2}\right] .8 .5 \mathrm{H}_{2} \mathrm{O} \frac{29-236^{\circ} \mathrm{C}}{\text { Loss of } 4.5 \mathrm{H}_{2} \mathrm{O}}\left[\mathrm{Mn}_{2}\left(\mathrm{C}_{18} \mathrm{H}_{12} \mathrm{~N}_{8} \mathrm{O}_{4} \mathrm{~S}_{2}\right) \mathrm{Cl}_{2}(\mathrm{OH})_{2}\left(\mathrm{H}_{2} \mathrm{O}\right)_{2}\right] \cdot 4 \mathrm{H}_{2} \mathrm{O}} \\
& 236-340^{\circ} \mathrm{C} \\
& \text { Loss of } \\
& {\left[4 \mathrm{H}_{2} \mathrm{O}_{\text {(Lattice) }}+2 \mathrm{H}_{2} \mathrm{O}_{\text {(Coord. })}\right]} \\
& \mathrm{Mn}_{2} \mathrm{O}_{3}+7.5 \mathrm{C} \stackrel{577-800^{\circ} \mathrm{C}}{\text { Loss of } 3 \mathrm{C}}\left[\mathrm{Mn}_{2}\left(\mathrm{C}_{10.5} \mathrm{O}_{3}\right)\right] \underset{\text { Loss of }\left(2 \mathrm{OH}+\mathrm{Cl}_{2}+\mathrm{C}_{7.5} \mathrm{H}_{12} \mathrm{~N}_{8} \mathrm{OS} \mathrm{S}_{2}\right)}{3}\left[\mathrm{Mn}_{2}\left(\mathrm{C}_{18} \mathrm{H}_{12} \mathrm{~N}_{8} \mathrm{O}_{4} \mathrm{~S}_{2}\right) \mathrm{Cl}_{2}(\mathrm{OH})_{2}\right]
\end{aligned}
$$

pyrolysis stages validated its nonspontaneous nature. ${ }^{74}$ Also, the free activation energy value for successive thermal decomposition steps of each investigated complex denoted the increase in $T \Delta S^{*}$ values from one step to another, which may be raised from the rigid structure of the remaining decomposition part after loss of the crystallized solvent, coordinated water and anions, that requires more energy for its rearrangement before proceeding to any structural change. ${ }^{75}$

4 The positive enthalpy values $\Delta H^{*}$ in all decomposition steps revealed an endothermic process. ${ }^{76}$ The frequency factor $(A)$ corresponds to the freedom degree of the activated complex. The small calculated values were associated with a rigid activated complex without any degree of freedom.

5 The negative entropy values for all of the compounds indicated that the transition states are more ordered than the reactants in a less random molecular arrangement. Also, the reactions were slow. ${ }^{78}$ The more ordered character could be owing to bond polarization in the active state, which could happen via charge-transfer electronic transitions. ${ }^{79}$ The fractionated reaction order $(n)$ confirmed the complicated manner of reactions. ${ }^{80}$

2.4. XRD Studies. $\mathrm{Cu}(\mathrm{II}), \mathrm{Zn}$ (II), and $\mathrm{Fe}(\mathrm{III})$ complexes were examined by XRD in the range of $5-90^{\circ}$ at a wavelength of $1.543 \AA$ (Figure 5). $\mathrm{Zn}$ (II) had higher crystallinity than $\mathrm{Fe}(\mathrm{III})$ and $\mathrm{Cu}(\mathrm{II})$ complexes. $\mathrm{Zn}$ (II) and $\mathrm{Fe}(\mathrm{III})$ complexes were consistent with a tetragonal with space group $\mathrm{P}$ and a monoclinic with space group $P 2_{1} / n(14)$ from card numbers (00-059-1278) and (00-054-1809), respectively. The unit cells of $\mathrm{Zn}$ (II) and $\mathrm{Fe}$ (III) complexes had lattice constants of $a=$ 19.612, $b=19.612$, and $c=14.286 \AA$ and $a=7.824, b=$ 17.197, and $c=21.857 \AA$, respectively. Scherrer's equation was employed for calculating the average sizes of 42 and $27 \mathrm{~nm}$ for $\mathrm{Zn}$ (II) and $\mathrm{Fe}$ (III) chelates, respectively, confirming their nanostructure. ${ }^{81,82}$

$\left[\mathrm{Fe}_{2}\left(\mathrm{H}_{4} \mathrm{~L}\right) \mathrm{Cl}_{4}(\mathrm{OH})_{2}\left(\mathrm{H}_{2} \mathrm{O}\right)_{2}\right] \cdot 6.5 \mathrm{H}_{2} \mathrm{O} \cdot 0.5 \mathrm{EtOH}$ acted as a precursor for the preparation of nanosized iron oxide. XRD analysis confirmed its composition and its nanosize. Figure S1 shows diffraction angles $(2 \theta)$ at 33.22, 35.71, 40.94, 49.54, $54.15,62.52$, and 64.08 corresponding to $104,110,113,024$, 116,214 , and 300 miller indices, respectively, characteristic of $\mathrm{Fe}_{2} \mathrm{O}_{3}$ with less intense peaks of $\mathrm{Fe}_{3} \mathrm{O}_{4}$ based on card numbers 96-901-5965 and 96-900-5817. The oxide was crystallized into a hexagonal shape with a nanosize of $13 \mathrm{~nm}$.

2.5. TEM Study of the Fe(III) Complex and Its Thermogravimetric Residual Metal Oxide. The morphological characteristics of the as-prepared samples were investigated using a transmission electron microscope. Figure 6 illustrates the shape evolution of the nanoparticles upon the thermal treatment of the iron complex. Figure 6a shows that the Fe(III) complex appears as irregular-shaped, agglomerated nanosized particles of $25-30 \mathrm{~nm}$. Figure $6 \mathrm{~b}$ shows the morphological evolution of the irregularly shaped agglomerated nanoparticles to a predominately quasi-spherical morphology upon the thermal pyrolysis of the iron complex. The size of $\mathrm{Fe}_{2} \mathrm{O}_{3}$ nanoparticles was approximately $20 \mathrm{~nm}$. The $\mathrm{XRD}$ and TEM particle sizes were different because the XRD particle is the crystallized size or primary particle, which is a single crystal particle, but that of TEM is a particle consisting of one or two or even more primary particles. ${ }^{83}$

2.6. Biological Activity. 2.6.1. Cytotoxic Activity. The HepG-2 human liver cancer cell line was treated with the prepared compounds, and the results were mentioned as $\mathrm{IC}_{50}$ values. The metal chelates exhibit high remarkable antitumor

Scheme 4. Thermal Decomposition Pathway of $\mathrm{Cu}$ (II) and Ni(II) Chelates

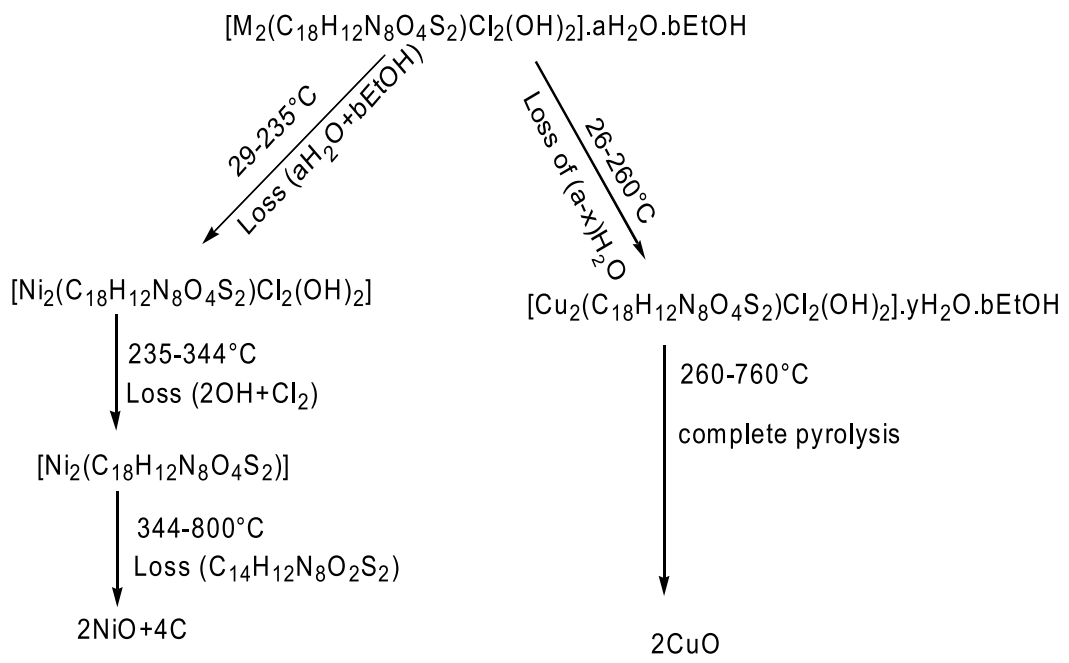

\begin{tabular}{lcccc}
\hline $\mathrm{M}$ & $\mathrm{a}$ & $\mathrm{b}$ & $\mathrm{x}$ & $\mathrm{y}$ \\
\hline $\mathrm{Ni}(\mathrm{II})$ & 7.5 & 0.5 & - & - \\
$\mathrm{Cu}(\mathrm{II})$ & 1 & 5.5 & 5 & 0.5
\end{tabular}



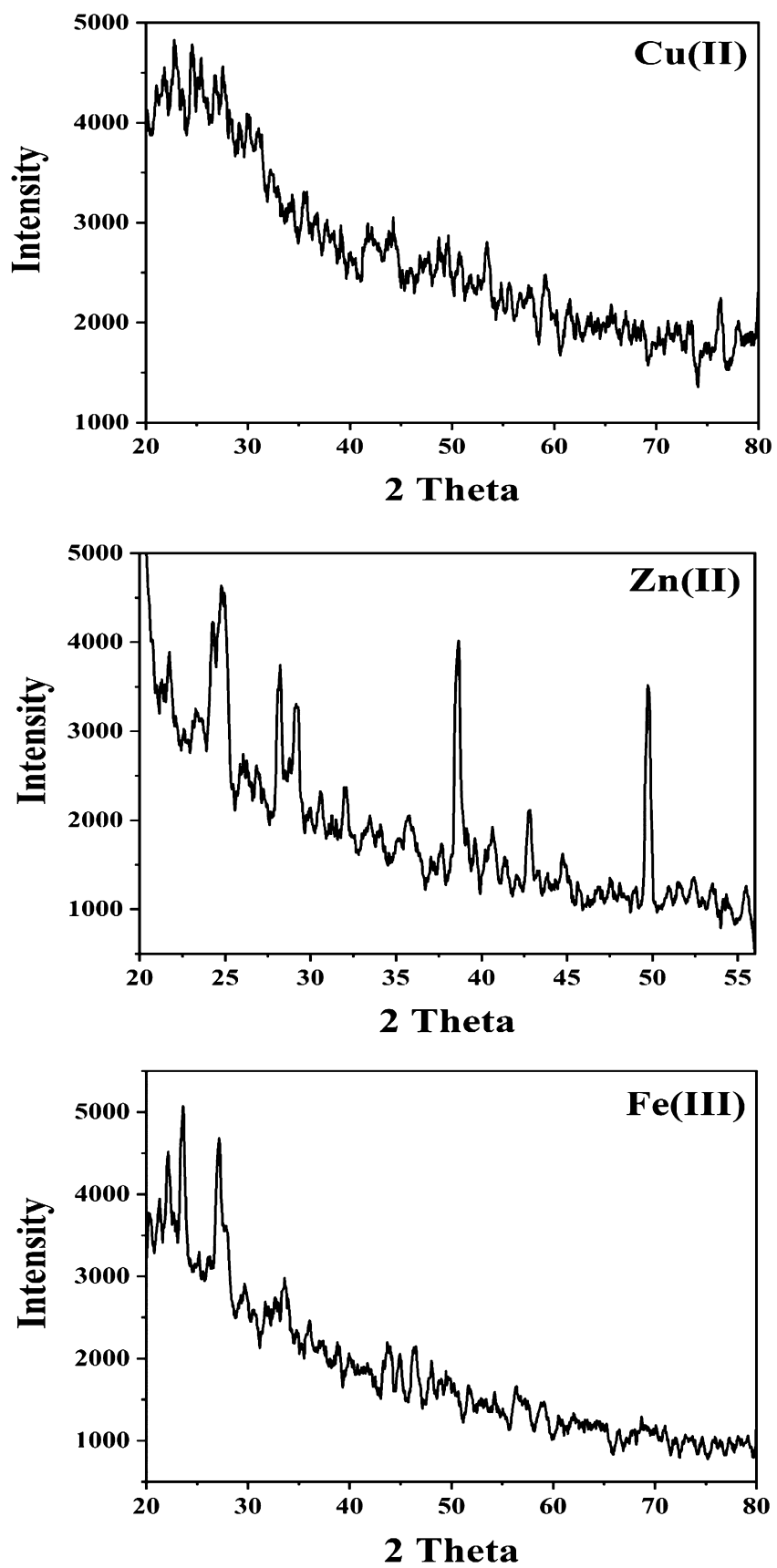

Figure 5. XRD diffractograms of $\mathrm{Cu}(\mathrm{II}), \mathrm{Zn}(\mathrm{II})$, and $\mathrm{Fe}(\mathrm{III})$ complexes.

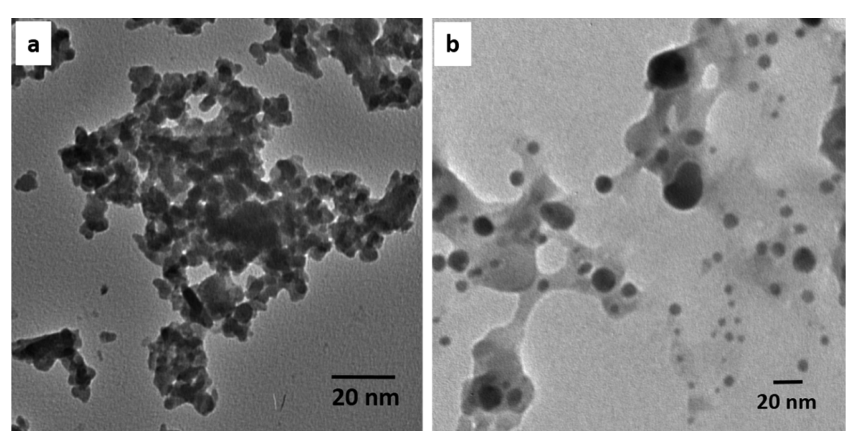

Figure 6. Transmission electron micrographs of the (a) $\mathrm{Fe}(\mathrm{III})$ complex and (b) residual $\mathrm{Fe}_{2} \mathrm{O}_{3}$. activity rather than the free ligand with low $\mathrm{IC}_{50}$. Meanwhile, the $\mathrm{Cu}$ (II) complex had a high $\mathrm{IC}_{50}$ (lower cytotoxic activity) relative to other complexes (Table 7 ). The anticancer activity of complexes was arranged in the following order

$$
\mathrm{Fe}_{2} \mathrm{O}_{3}>\mathrm{Fe}(\mathrm{III})>\mathrm{Zn}(\mathrm{II})>\mathrm{Co}(\mathrm{II}) \gg \mathrm{Cu}(\mathrm{II}) \gg \gg \mathrm{H}_{4} \mathrm{~L}
$$

At low concentration $(3.9 \mu \mathrm{g} / \mathrm{mL})$, the cell viability (\%) decreased in treating cell lines with $\mathrm{Fe}(\mathrm{III}), \mathrm{Zn}$ (II), and $\mathrm{Co}$ (II) complexes and decreased continuously by increasing the concentration, but the effect of the $\mathrm{Cu}$ (II) complex on the cell line appeared at $7.8 \mu \mathrm{g} / \mathrm{mL}$, while the effect of the ligand was observed at $62.5 \mu \mathrm{g} / \mathrm{mL}$. This implied that the activity depended on the tested solution concentration. The studies showed that the coupling of different metal ions with anchoring agents demonstrated marked changes in anticancer activity. According to Tweedy's chelation theory, the metal ion had a positive charge at the moment of chelation, which increased the acidity of the ligand that accepted protons. Furthermore, the charge equilibration reduced their polarization ability, causing the chemicals to diffuse through the lipid. ${ }^{84}$ Also, the complexes disrupted the cell's respiration process, preventing protein synthesis and hence preventing tumor cell development. The Fe(III) chelate displayed a notable anticancer impact because of its charge and ionic radii. Because the $\mathrm{Fe}$ (III) metal ion possessed the highest positive charge, ligand orbital overlap and partial sharing of the metal ion's positive charge with donor groups occurred, suppressing the metal ion's polarity to a large amount. It also boosted the delocalization of electrons across the entire chelate ring, as well as the complex's lipophilicity. This enhanced lipophilicity aided in the penetration of the $\mathrm{Fe}$ (III) complex into lipid membranes and blocked the metal binding sites in tumor cells. ${ }^{85}$ The small size $(27 \mathrm{~nm})$ of the $\mathrm{Fe}(\mathrm{III})$ complex was also a key factor in its strong antitumor efficiency. It encouraged its incorporation into the cancer cell active sites and easy destruction. ${ }^{86} \mathrm{Zn}$ (II) has a nanosize structure $(42 \mathrm{~nm})$ that allows it to penetrate lipid membranes and influence tumor cells but at a lower effectiveness than the $\mathrm{Fe}$ (III) complex. On the other hand, the amorphous $\mathrm{Cu}$ (II) complex showed decreased activity because its structure prevented it from penetrating the lipid membrane.

Nanoparticles are smaller than several hundred biological molecules such as antibodies, enzymes, and receptors. $\mathrm{Fe}_{2} \mathrm{O}_{3}$ oxide with particle size $(13 \mathrm{~nm})$ showed high cytotoxic activity against the HepG-2 cell line with $\mathrm{IC}_{50}=8.12 \mu \mathrm{g} / \mathrm{mL}$ when compared to all the tested compounds with $\left(\mathrm{IC}_{50}=10.1-245\right.$ $\mu \mathrm{g} / \mathrm{mL}$ ) because of its biocompatible surface for cell attachment and proliferation. By virtue of its small size, it can interact with cell surfaces and enter biological systems through various routes; it can gain access to cellular and tissue regions that are not accessible to larger particles. Because of the negative charge of the surface, they were easy to incorporate into hydrophobic and hydrophilic systems and easy to functionalize with various molecules, making them a viable tool for biological applications. ${ }^{87,88}$

2.6.2. Antioxidant Activity. The antioxidant activity was studied using the 2,2-diphenyl-1-picrylhydrazyl (DPPH) free radical. The method relied on the antioxidants' ability to give an electron or hydrogen to the free radical. The decrease in $\mathrm{DPPH}$ absorbance at $517 \mathrm{~nm}$ was used to detect the increase in DPPH stability after the gain of hydrogen or an electron. Table 8 shows that the antioxidant activity was a function of concentration. By increasing the concentration of the tested compound, its activity increased. Also, Table 8 shows that the 
Table 7. In Vitro Anticancer Screening of the $\left(\mathrm{H}_{4} \mathrm{~L}\right)$ Ligand and Its Metal Chelates

\begin{tabular}{|c|c|c|c|c|c|c|c|c|c|c|}
\hline \multirow{2}{*}{$\begin{array}{l}\text { conc. }(\mu \mathrm{g} / \mathrm{mL}) \\
\text { sample }\end{array}$} & 0 & 3.9 & 7.8 & 15.6 & 31.25 & 62.5 & 125 & 250 & 500 & $\mathrm{IC}_{50}(\mu \mathrm{g} / \mathrm{mL})$ \\
\hline & \multicolumn{10}{|c|}{ cell viability (\%) } \\
\hline $\mathrm{H}_{4} \mathrm{~L}$ & 100 & 100 & 100 & 100 & 99.43 & 96.24 & 79.02 & 48.75 & 21.94 & 245 \\
\hline$\left[\mathrm{Co}_{2}\left(\mathrm{H}_{4} \mathrm{~L}\right) \mathrm{Cl}_{2}(\mathrm{OH})_{2}\right] \cdot 8.5 \mathrm{H}_{2} \mathrm{O} \cdot 2 \mathrm{EtOH}$ & 100 & 85.12 & 76.45 & 57.02 & 40.89 & 27.94 & 16.23 & 7.80 & 2.68 & 21.1 \\
\hline$\left[\mathrm{Cu}_{2}\left(\mathrm{H}_{4} \mathrm{~L}\right) \mathrm{Cl}_{2}(\mathrm{OH})_{2}\right] \cdot \mathrm{H}_{2} \mathrm{O} \cdot 5.5 \mathrm{EtOH}$ & 100 & 100 & 97.18 & 91.32 & 78.64 & 47.56 & 31.83 & 19.41 & 7.85 & 57.6 \\
\hline$\left[\mathrm{Zn}_{2}\left(\mathrm{H}_{4} \mathrm{~L}\right) \mathrm{Cl}_{2}(\mathrm{OH})_{2}\left(\mathrm{H}_{2} \mathrm{O}\right)_{4}\right] \cdot 4 \mathrm{H}_{2} \mathrm{O} \cdot 1.5 \mathrm{EtOH}$ & 100 & 84.61 & 71.83 & 54.29 & 38.67 & 25.39 & 14.65 & 6.93 & 2.14 & 18.7 \\
\hline$\left[\mathrm{Fe}_{2}\left(\mathrm{H}_{4} \mathrm{~L}\right) \mathrm{Cl}_{4}(\mathrm{OH})_{2}\left(\mathrm{H}_{2} \mathrm{O}\right)_{2}\right] \cdot 6.5 \mathrm{H}_{2} \mathrm{O} \cdot 0.5 \mathrm{EtOH}$ & 100 & 70.93 & 56.07 & 39.86 & 24.15 & 11.87 & 6.38 & 2.96 & 0.89 & 10.1 \\
\hline residual $\mathrm{Fe}_{2} \mathrm{O}_{3}$ & 100 & 64.08 & 51.27 & 39.42 & 26.38 & 19.54 & 12.53 & 7.82 & 3.58 & 8.12 \\
\hline
\end{tabular}

Table 8. DPPH Scavenging Activity of $\left(\mathrm{H}_{4} \mathrm{~L}\right)$ Ligand and Its Metal Chelates

\begin{tabular}{|c|c|c|c|c|c|c|c|c|c|c|}
\hline conc. $(\mu \mathrm{g} / \mathrm{mL})$ & 0 & 6.25 & 12.25 & 25 & 50 & 100 & 200 & 400 & 800 & $\mathrm{IC}_{50}(\mu \mathrm{g} / \mathrm{mL})$ \\
\hline sample & \multicolumn{10}{|c|}{ DPPH scavenging \% } \\
\hline $\mathrm{H}_{4} \mathrm{~L}$ & 0 & 0.23 & 0.47 & 1.98 & 2.86 & 5.93 & 11.67 & 16.54 & 27.41 & high \\
\hline$\left[\mathrm{Co}_{2}\left(\mathrm{H}_{4} \mathrm{~L}\right) \mathrm{Cl}_{2}(\mathrm{OH})_{2}\right] \cdot 8.5 \mathrm{H}_{2} \mathrm{O} \cdot 2 \mathrm{EtOH}$ & 0 & 3.83 & 21.06 & 37.65 & 66.28 & 85.60 & 90.24 & 93.89 & 95.68 & 37.2 \\
\hline$\left[\mathrm{Cu}_{2}\left(\mathrm{H}_{4} \mathrm{~L}\right) \mathrm{Cl}_{2}(\mathrm{OH})_{2}\right] \cdot \mathrm{H}_{2} \mathrm{O} \cdot 5.5 \mathrm{EtOH}$ & 0 & 0.25 & 0.47 & 1.98 & 2.86 & 5.93 & 11.67 & 16.54 & 27.41 & high \\
\hline$\left[\mathrm{Zn}_{2}\left(\mathrm{H}_{4} \mathrm{~L}\right) \mathrm{Cl}_{2}(\mathrm{OH})_{2}\left(\mathrm{H}_{2} \mathrm{O}\right)_{4}\right] \cdot 4 \mathrm{H}_{2} \mathrm{O} \cdot 1.5 \mathrm{EtOH}$ & 0 & 5.52 & 18.97 & 30.94 & 53.86 & 81.78 & 89.19 & 92.71 & 94.12 & 45.8 \\
\hline$\left[\mathrm{Fe}_{2}\left(\mathrm{H}_{4} \mathrm{~L}\right) \mathrm{Cl}_{4}(\mathrm{OH})_{2}\left(\mathrm{H}_{2} \mathrm{O}\right)_{2}\right] \cdot 6.5 \mathrm{H}_{2} \mathrm{O} \cdot 0.5 \mathrm{EtOH}$ & 0 & 0.59 & 5.78 & 20.36 & 36.08 & 56.41 & 70.52 & 88.43 & 93.67 & 84.2 \\
\hline
\end{tabular}

investigated metal complexes, with the exception of the $\mathrm{Cu}$ (II) complex, displayed significant antioxidant activity in comparison to the ligand. It is clear that coordination can boost the scavenger action, and it relies on varying the metal ions. ${ }^{17}$ The highest antioxidant activity was observed for the $\mathrm{Co}$ (II) complex with the lowest IC $_{50}(37.26 \mu \mathrm{g} / \mathrm{mL})$ because $\mathrm{Co}$ (II) was a powerful reducing agent with more than one oxidation state, facilitating electron donation to the free radical in vitro. The compounds' antioxidant activity was sorted in the following order

$$
\mathrm{Co}(\mathrm{II})>\mathrm{Zn}(\mathrm{II})>\mathrm{Fe}(\mathrm{III})>\mathrm{Cu}(\mathrm{II})=\mathrm{H}_{4} \mathrm{~L}
$$

2.7. Theoretical Studies. 2.7.1. Charge Distribution Analysis. The charge analysis was used to predict the preferred ligand sites for chelation to the metal ion. It was noted that carbonyl groups' oxygen atoms $(\mathrm{C}=\mathrm{O})$, the thione group's sulfur atom $(\mathrm{C}=\mathrm{S})$, and the imine group's nitrogen atom $(\mathrm{C}=\mathrm{N})$ possessed a high negative atomic charge, making them favorable for coordination with metal ions. ${ }^{89}$ Meanwhile, N11 and N12 (azo groups) were not susceptible to chelation because they had high positive and low negative charges, respectively (Table 9). All hydrogen atoms had a net positive charge, but due to the presence of an electronegative atom (N), H-amide had a higher positive charge than the other hydrogen atoms. ${ }^{90}$ Therefore, all of them behaved as acceptor atoms. The above theoretical studies supported the experimental data that discovered the ON/OS bidentate or ONS tridentate manner of the ligand with different metal ions, and this resulted from comparing the infrared spectra of complexes to those of free ligand.

The positive atomic charge of S32 (thiol) could be explained by the high electronegativity of adjacent azomethine nitrogen $(\mathrm{C}=\mathrm{N})$, which has a high negative atomic charge. In comparison, S31 (thione) had a high negative charge because the adjacent $\mathrm{NH}$ group was less electronegative (less withdrawing of electrons) than the $\mathrm{C}=\mathrm{N}$ group.

2.7.2. Molecular Modeling Study. The ligand molecular modeling study was performed by a Chem3D 15.0 application platform to detect some parameters and the geometrical shape (Figure 7). The optimum ligand bond lengths were identified in order to determine the manner of bonding to metal ions and the thermal behavior. The most important length was the
Table 9. Charges of $\left(\mathrm{H}_{4} \mathrm{~L}\right)$ Ligand Atoms

$\begin{array}{llll}\text { atom (type) } & \text { charge } & \text { atom (type) } & \text { charge } \\ \text { C1 (alkene) } & -0.159 & \mathrm{~N} 23 \text { (amide) } & 0.2845 \\ \text { C2 (alkene) } & -0.094 & \mathrm{C} 24 \text { (thiocarbo) } & 0.3095 \\ \text { C3 (alkene) } & -0.277 & \mathrm{~N} 25 \text { (amide) } & 0.2847 \\ \text { C4 (alkene) } & 0.028 & \mathrm{C} 26 \text { (carbonyl) } & 0.4436 \\ \text { C5 (alkene) } & 0.0451 & \text { O27 (carbonyl) } & -0.7250 \\ \text { C6 (alkene) } & -0.0034 & \text { O28 (carbonyl) } & -0.7825 \\ \text { C7 (alkene) } & -0.035 & \text { O29 (carbonyl) } & -0.7454 \\ \text { C8 (alkene) } & -0.225 & \text { O30 (carbonyl) } & -0.7457 \\ \text { C9 (alkene) } & -0.093 & \text { S31 (thiocarbo) } & -0.5087 \\ \text { C10 (alkene) } & -0.278 & \text { S32 (thiol) } & 0.1771 \\ \text { N11 (imine) } & 0.8342 & \text { H33 } & 0.0212 \\ \text { N12 (imine) } & -0.1175 & \text { H34 } & 0.0221 \\ \text { N13 (imine) } & 0.4329 & \text { H35 } & 0.0191 \\ \text { N14 (imine) } & -0.2883 & \text { H36 } & 0.0201 \\ \text { C15 (alkane) } & 0.02088 & \text { H37 } & 0.0178 \\ \text { C16 (alkane) } & 0.0189 & \text { H38 } & 0.0201 \\ \text { C17 (carbonyl) } & 0.4622 & \text { H39 } & 0.0282 \\ \text { N18 (amide) } & 0.3258 & \text { H40 } & 0.0282 \\ \text { C19 (alkene) } & 0.3703 & \text { H41 } & 0.0991 \\ \text { N20 (imine) } & -0.3714 & \text { H42 (amide) } & 0.0970 \\ \text { C21 (carbonyl) } & 0.4840 & \text { H43 (amide) } & 0.0970 \\ \text { C22 (carbonyl) } & 0.4449 & \text { H44 (thiol) } & 0.0281\end{array}$

distance between $\mathrm{C} 15-\mathrm{C} 17, \mathrm{C} 15-\mathrm{C} 21, \mathrm{C} 16-\mathrm{C} 26$, and $\mathrm{C} 16-$ $\mathrm{C} 22=1.529 \AA$, where the mass fragmentation occurred. It was a weak bond, but it was not the weakest. The other bond lengths $(\AA)$ were as follows

$$
\begin{aligned}
& \mathrm{C} 1-\mathrm{C} 2=\mathrm{C} 1-\mathrm{C} 6=\mathrm{C} 1-\mathrm{C} 7=1.404, \\
& \mathrm{C} 15-\mathrm{C} 21=\mathrm{C} 15-\mathrm{C} 17=\mathrm{C} 16-\mathrm{C} 26=1.523, \\
& \mathrm{C} 19-\mathrm{S} 31=1.815, \quad \mathrm{C} 24-\mathrm{S} 32=1.576, \\
& \mathrm{~N} 11-\mathrm{N} 13=\mathrm{N} 12-\mathrm{N} 14=1.248, \\
& \mathrm{C} 17-\mathrm{N} 18=\mathrm{C} 26-\mathrm{N} 25=1.470
\end{aligned}
$$

The lengths of most ligand linkages deviated somewhat after complexation, indicating that the coordination process was successful (Table 10). For example, $\mathrm{Cu}-\mathrm{O}$ (1.795 $\AA$ ) and $\mathrm{Ni}-$ $\mathrm{N}(1.874 \AA)$ bond lengths were calculated to be longer than 

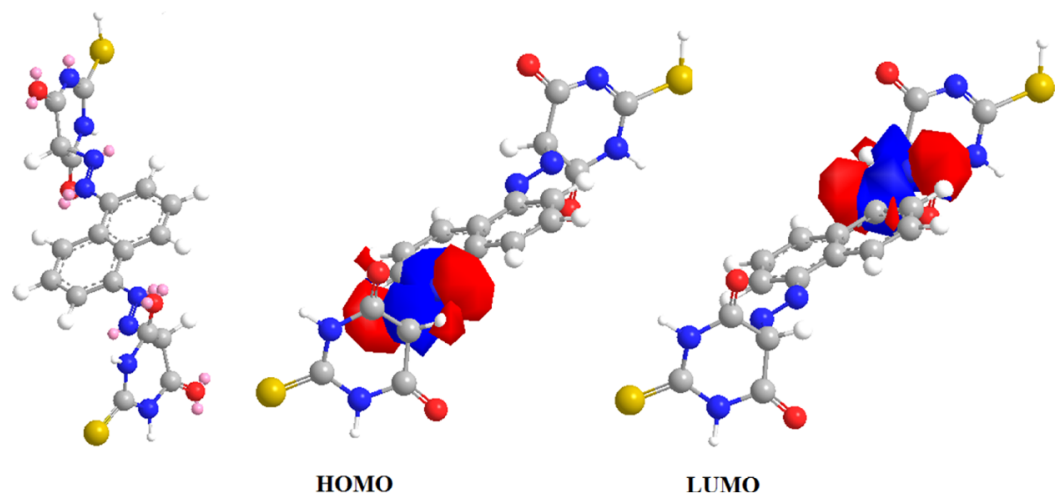

Figure 7. Molecular modeling of the $\left(\mathbf{H}_{4} \mathbf{L}\right)$ azo dye ligand.

Table 10. Some Important Bond Lengths of the $\left(H_{4} L\right)$ Ligand

\begin{tabular}{|c|c|c|c|c|c|c|c|}
\hline bond length & $\mathrm{H}_{2} \mathrm{~L}$ & $\mathrm{Mn}(\mathrm{II})$ & $\mathrm{Co}(\mathrm{II})$ & $\mathrm{Ni}(\mathrm{II})$ & $\mathrm{Cu}(\mathrm{II})$ & $\mathrm{Zn}(\mathrm{II})$ & $\mathrm{Fe}(\mathrm{III})$ \\
\hline $\mathrm{C} 15-\mathrm{C} 21=\mathrm{C} 15-\mathrm{C} 17$ & 1.529 & 1.542 & 1.533 & 1.518 & 1.529 & 1.535 & 1.719 \\
\hline $\mathrm{N} 12-\mathrm{N} 14=\mathrm{N} 11-\mathrm{N} 13$ & 1.248 & 1.253 & 1.254 & 1.253 & 1.255 & 1.212 & 1.226 \\
\hline $\mathrm{C} 1-\mathrm{C} 6=\mathrm{C} 1-\mathrm{C} 2=\mathrm{C} 1-\mathrm{C} 7=$ & 1.414 & 1.366 & 1.360 & 1.350 & 1.359 & 1.366 & 1.291 \\
\hline $\mathrm{C} 17-\mathrm{N} 18=\mathrm{C} 26-\mathrm{N} 25$ & 1.470 & 1.359 & 1.364 & 1.376 & 1.357 & 1.362 & 1.344 \\
\hline C19-S31 & 1.815 & 1.916 & 1.859 & 1.877 & 1.881 & 1.843 & 1.843 \\
\hline C24-S32 & 1.576 & 1.918 & 1.874 & 1.826 & 1.882 & 1.818 & 1.736 \\
\hline M33-N18 & - & 1.899 & - & 1.874 & 1.554 & 1.963 & - \\
\hline M33-O28 & - & 1.816 & 0.873 & 1.786 & 1.795 & 1.893 & 1.858 \\
\hline $\mathrm{M} 33-\mathrm{Cl}$ & - & 2.167 & 2.145 & 2.130 & 2.164 & 2.245 & 2.255 \\
\hline M33-O (hydroxyl) & - & 1.813 & 0.703 & 1.781 & 1.815 & 1.920 & 1.910 \\
\hline M33-S31 & - & 2.211 & 2.182 & - & 2.208 & - & 2.303 \\
\hline M34-N25 & - & 1.899 & - & 1.875 & 1.549 & 1.961 & - \\
\hline M34-S32 & - & 2.212 & 2.173 & - & 2.207 & - & 2.226 \\
\hline M34-O30 & - & 1.817 & 0.865 & 1.785 & 1.796 & 1.871 & 1.831 \\
\hline M34-Cl & - & 2.168 & 2.147 & 2.131 & 2.162 & 2.242 & 2.212 \\
\hline M34-O (hydroxyl) & - & 1.819 & 0.678 & 1.779 & 1.812 & 1.892 & 1.808 \\
\hline
\end{tabular}

the normal $\mathrm{M}-\mathrm{X}$ bond lengths of 1.62 and $1.44 \AA$, respectively. The $\mathrm{M}-\mathrm{O}, \mathrm{M}-\mathrm{N}$, and $\mathrm{M}-\mathrm{S}$ long bonds mean that their ionic character is small. ${ }^{91}$ Also, all complexes' $\mathrm{M}-\mathrm{O}$ and $\mathrm{M}-\mathrm{OH}$ bond lengths were stronger (shorter) than those of $\mathrm{M}-\mathrm{Cl}, \mathrm{M}-$ $\mathrm{N}$, and $\mathrm{M}-\mathrm{S}$, emphasizing the outcome of metal oxides as a final residue from the thermal pyrolysis of metal chelates.

Several attempts to generate suitable crystals for X-ray crystallography were unsuccessful. Because of this issue, the geometries were theoretically optimized to support the experimental findings. The ligand and $\mathrm{Mn}$ (II) complexoptimized geometries are illustrated as a representative example in Figures 7 and 8. Table 11 shows the energy of the ground state as well as other factors. When we look at the HOMO and LUMO energies, HOMO is related to the electron-donating capacity and LUMO is about the ability to accept electrons. ${ }^{92}$ The studied $\left(\mathrm{H}_{4} \mathrm{~L}\right)$ ligand had $E_{\mathrm{HOMO}}>$ $E_{\text {LUMO, }}$ so it had a high ability for electron donation. The computed energy gap $E_{\mathrm{g}}$ is a crucial stability indicator that aids in the identification of a molecule's chemical reactivity and kinetic stability. ${ }^{93}$ The ligand to central metal ion electronic charge transfer increases as the $E_{\mathrm{g}}$ drops, making it easier to offer electrons to an acceptor. Low energy gap values can also be attributed to the groups that conjugate. ${ }^{94}$ By that, the $\left(\mathrm{H}_{4} \mathrm{~L}\right)$ ligand was more polarized, more reactive, and less kinetically stable by comparison with metal complexes. ${ }^{95}$ This supported the experimental data (TGA) that confirmed the stability of complexes rather than the ligand.

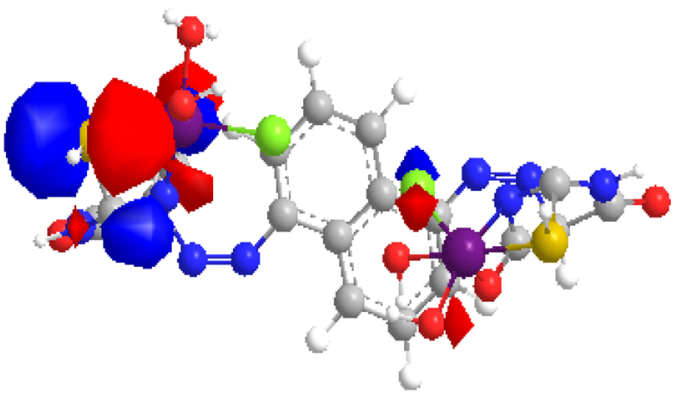

(a)

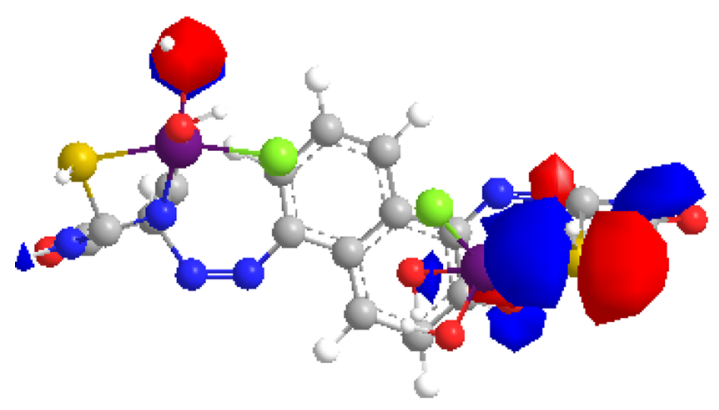

(b)

Figure 8. Graphical representation of (a) HOMO and (b) LOMO of the $\mathrm{Mn}(\mathrm{II})$ complex. 
Table 11. Computed Molecular Descriptions of All Synthesized Compounds

\begin{tabular}{|c|c|c|c|c|c|c|c|}
\hline \multirow[b]{2}{*}{ parameters } & \multicolumn{7}{|c|}{ Compounds } \\
\hline & $\mathrm{H}_{4} \mathrm{~L}$ & $\mathrm{Mn}(\mathrm{II})$ & $\mathrm{Co}(\mathrm{II})$ & $\mathrm{Ni}(\mathrm{II})$ & $\mathrm{Cu}(\mathrm{II})$ & $\mathrm{Zn}(\mathrm{II})$ & $\mathrm{Fe}(\mathrm{III})$ \\
\hline total energy & 37.94 & 2024.36 & 3993.69 & 1904.0 & 2049.3 & 2046.25 & 2664.73 \\
\hline HOMO $(\mathrm{eV})$ & -3.182 & -9.012 & -3.515 & -6.239 & -5.159 & -3.727 & -2.387 \\
\hline LUMO $(\mathrm{eV})$ & -3.157 & -8.875 & -3.060 & -5.198 & -3.687 & -2.079 & -2.136 \\
\hline energy Gap (eV) & 0.025 & 0.137 & 0.455 & 1.041 & 1.472 & 1.648 & 0.251 \\
\hline chemical potential $(\mu, \mathrm{eV})=E_{\mathrm{LUMO}}-E_{\mathrm{HOMO}} / 2$ & -0.012 & -0.068 & -0.227 & -0.520 & -0.736 & -0.824 & -0.125 \\
\hline electronegativity $(\chi=-\mu)$ & 0.012 & 0.068 & 0.227 & 0.520 & 0.736 & 0.824 & 0.125 \\
\hline chemical hardness $(\eta, \mathrm{eV})$ & 0.025 & 0.137 & 0.455 & 1.041 & 1.472 & 1.648 & 0.251 \\
\hline global softness $\left(\mathrm{S}, \mathrm{eV}^{-1}\right)$ & 40 & 7.299 & 2.197 & 0.960 & 0.679 & 0.606 & 3.98 \\
\hline electrophilicity index $\left(\omega=\mu^{2} / 2 \eta\right)$ & 0.002 & 0.013 & 0.056 & 0.129 & 0.184 & 0.206 & 0.031 \\
\hline
\end{tabular}

Hardness, softness, electronegativity, and chemical potential have been estimated as global reactivity descriptors for the examined metal chelates and neutral ligands. The ability of a molecular system to exchange electrons in the nonexcited state was related to the chemical potential value, while the resistance to electron density loss was determined as electronegativity. ${ }^{96}$ The hardness and softness of a molecule are vital in determining its stability and reactivity. ${ }^{96}$ The hard molecule has a large energy gap, whereas the soft molecule has a smaller one. ${ }^{95}$ The investigated $\left(\mathrm{H}_{4} \mathrm{~L}\right)$ ligand can be considered as a soft molecule and the complexes are hard molecules. The molecules with the lowest global hardness values should be more reactive than the others, reflecting that the ligand was more reactive. The metal complexes were arranged according to their reactivity as follows

$$
\mathrm{Mn}(\mathrm{III})>\mathrm{Fe}(\mathrm{III})>\mathrm{Co}(\mathrm{II})>\mathrm{Ni}(\mathrm{II})>\mathrm{Cu}(\mathrm{II})>\mathrm{Zn}(\mathrm{II})
$$

The theoretical studies supported the biological results and explained why metal complexes have more biological activity than their ligands. Because the complexes had a higher calculated energy gap than the ligand, they were less polarized, allowing them to diffuse through the lipid layer and perform their effect on the protein synthesis, which inhibits tumor cell development.

\section{CONCLUSIONS}

The azo dye ligand constructed binuclear metal complexes with $\mathrm{Mn}(\mathrm{II}), \mathrm{Co}(\mathrm{II}), \mathrm{Ni}(\mathrm{II}), \mathrm{Cu}(\mathrm{II}), \mathrm{Zn}(\mathrm{II})$, and $\mathrm{Fe}(\mathrm{III})$ chloride salts. The obtained chelates were elucidated by various physicochemical tools. While coordinating the ligand to metal ions, it was in the neutral-keto-thiol form. Octahedral, tetrahedral, and square bipyramidal geometries were proposed for $[\mathrm{Mn}(\mathrm{II}), \mathrm{Zn}(\mathrm{II})$, and $\mathrm{Fe}(\mathrm{III})]$; $[\mathrm{Co}(\mathrm{II})$ and $\mathrm{Ni}(\mathrm{II})]$; and $\mathrm{Cu}(\mathrm{II})$ complexes, respectively. $\mathrm{Fe}_{2} \mathrm{O}_{3}, \mathrm{Fe}(\mathrm{III})$, and $\mathrm{Zn}(\mathrm{II})$ complexes were found in the nanostructure by XRD examination. The novel azo dye and some of its chelates were evaluated against the HepG-2 cell line. The nanosized $\mathrm{Fe}_{2} \mathrm{O}_{3}$ exhibited higher activity than its precursor $\mathrm{Fe}$ (III) complex, while $\mathrm{Co}$ (II) had high antioxidant activity. Some experimental results were interpreted by theoretical studies.

\section{EXPERIMENTAL SECTION}

4.1. Chemicals and Instruments. Commercial reagentgrade chemicals were utilized without further purification. At Al-Azhar University, (C, H, and N) analyses were carried out using a PerkinElmer-2400 elemental analyzer. The metal and chloride ions of the obtained chelates were determined by complexometric titration and Mohr's method, respectively. ${ }^{97}$ Using a Nicolet FT-IR spectrophotometer, infrared spectra in the range of $4000-400 \mathrm{~cm}^{-1}$ were recorded. The Shimadzu QP-2010 Plus spectrometer, EI Full ms (40.00-1000.00) is used for obtaining FAB mass spectra of the ligand and some of its chelates. The ${ }^{1} \mathrm{H}$ NMR spectra were recorded in DMSO at $400 \mathrm{MHz}$ using a Bruker FT-NMR spectrometer. The Nujol mulls absorption electronic spectra were recorded using a PerkinElmer Lambda 4B spectrophotometer. In a $10^{-3} \mathrm{M}$ DMSO solution, the molar conductance of each complex was measured using a type CD6N Tacussel conductimeter. The thermogravimetric analyses (TG and DTG) were carried out using a Shimadzu DAT/TG-50 thermal analyzer with a heating rate of $10{ }^{\circ} \mathrm{C} / \mathrm{min}$ and a flow rate of $20 \mathrm{~mL} / \mathrm{min}$ from room temperature to $900{ }^{\circ} \mathrm{C}$ using a platinum crucible. The Gouy method was used to determine the magnetic susceptibilities at room temperature. An X-ray diffractometer with nickel $\mathrm{Cu} \mathrm{K}_{\alpha}$ radiation $\left(\lambda=1.5418 \mathrm{~A}^{\circ}\right)$ and a graphite monochromator with $2 \theta$ in the range of $5-90^{\circ}$ were employed to study the XRD pattern of $\mathrm{Cu}(\mathrm{II}), \mathrm{Zn}(\mathrm{II}), \mathrm{Fe}(\mathrm{III})$ complexes, and $\mathrm{Fe}_{2} \mathrm{O}_{3}$. A JEOL-(JEM) 1230 transmission electron microscope was used to examine the ethanolic suspensions of chemicals that were put onto copper grids and air-dried. Antitumor and antioxidant activities of the ligand and its chelates were scrutinized at AlAzhar University's Regional Center for Mycology and Biotechnology (RCMB).

4.2. Synthesis of the Azo Dye Ligand. Naphthalene-1,5diamine ( $1 \mathrm{~mol}, 0.158 \mathrm{~g})$ was dissolved in concentrated sulfuric acid. The resulted amine sulfate salt was dissolved in distilled water. The obtained solution was cooled below $5{ }^{\circ} \mathrm{C}$ in an ice-bath. The diazonium solution was formed by the addition of cooled aqueous sodium nitrite solution $(2 \mathrm{~mol}$, $0.87 \mathrm{~g}$ ) to the amine salt solution, slowly with constant stirring at $5{ }^{\circ} \mathrm{C}$. The diazonium solution was added portion-wise to the basic coupling-phenol mixture, which was prepared by dissolving TBA ( $2 \mathrm{~mol}, 0.144 \mathrm{~g}$ ) in $10 \mathrm{~mL}$ of aqueous sodium hydroxide ( 2 mol, $0.50 \mathrm{~g}$ ). Cold $\mathrm{HCl}$ was added to achieve complete precipitation until a $\mathrm{pH}$ of 6 was reached. The crude reddish-brown dye was collected by filtration, ethanol washing, and drying in a vacuum desiccator over anhydrous $\mathrm{CaCl}_{2}$. The ligand's melting point was found to be $315^{\circ} \mathrm{C}$.

The chelated compounds have been prepared by the slow addition of a warm ethanolic solution of appropriate metal chloride salts, where $[\mathrm{M}=\mathrm{Mn}(\mathrm{II}), \mathrm{Co}(\mathrm{II}), \mathrm{Ni}(\mathrm{II}), \mathrm{Cu}(\mathrm{II})$, $\mathrm{Zn}(\mathrm{II})$, and $\mathrm{Fe}(\mathrm{III})](2 \mathrm{~mol})$, to $10 \mathrm{~mL}$ of a warm ethanolic solution of suspended ligand ( $1 \mathrm{~mol}, 1 \mathrm{~g})$ with continuous magnetic stirring. The reaction components were left for $5 \mathrm{~h}$ at $80{ }^{\circ} \mathrm{C}$, and then, the colored complexes were filtered off, washed with ethanol, and dried in desiccators over anhydrous $\mathrm{CaCl}_{2}$. Their melting point was over $360{ }^{\circ} \mathrm{C}$. 
4.3. Preparation of Nanosized $\mathrm{Fe}_{2} \mathrm{O}_{3}$ from Its Corresponding Complex. The $\mathrm{Fe}$ (III) complex was calcined at $600{ }^{\circ} \mathrm{C}$ in air with a heating rate of $10{ }^{\circ} \mathrm{C} \mathrm{min}{ }^{-1}$ to produce nanosized $\mathrm{Fe}_{2} \mathrm{O}_{3}$. ${ }^{98}$ The product was cooled to be analyzed by transition electron microscopy and powder X-ray.

4.4. Biological Activity. 4.4.1. Cytotoxic Activity. The ligand's and its chelates' cytotoxic effect on human hepatocellular carcinoma (HepG-2) was estimated, as previously described. ${ }^{17,27,99}$

4.4.2. Antioxidant Activity. As previously reported, the antioxidant activity of certain substances was spectrophotometrically evaluated using a DPPH free radical scavenging assay. ${ }^{27,100}$

\section{ASSOCIATED CONTENT}

\section{(s) Supporting Information}

The Supporting Information is available free of charge at https://pubs.acs.org/doi/10.1021/acsomega.1c02989.

Physicochemical characterization of 5-[5-(4,6-dioxo-2thioxo-hexahydro-pyrimidin-5-ylazo)-naphthalen-1ylazo]-2-mercapto- $1 \mathrm{H}$-pyrimidine-4,6-dione and its complexes; $\mathrm{C}, \mathrm{H}$, and $\mathrm{N}$ analysis; ${ }^{1} \mathrm{H}$ NMR images; infrared spectra; mass spectra; absorption electronic spectra; magnetic moment measurements; thermal studies; XRD patterns; biological activity; theoretical studies; and XRD pattern for $\mathrm{Fe}_{2} \mathrm{O}_{3}$ (PDF)

\section{AUTHOR INFORMATION}

\section{Corresponding Author}

Fatma I. Abouzayed - Chemistry Department, Faculty of Science, Menoufia University, Shebin El-Kom 048, Egypt; ๑ orcid.org/0000-0002-8732-5742;

Email: fatmaibrahim816@yahoo.commailto

\section{Authors}

Saeyda A. Abouel-Enein - Chemistry Department, Faculty of Science, Menoufia University, Shebin El-Kom 048, Egypt

Amira M. Hammad - Basic Science Department, Higher Institute of Engineering and Technology, Tanta 040, Egypt

Complete contact information is available at:

https://pubs.acs.org/10.1021/acsomega.1c02989

\section{Author Contributions}

All authors contributed to analyze the results and write the draft and the final version of the manuscript.

\section{Notes}

The authors declare no competing financial interest.

\section{ACKNOWLEDGMENTS}

We thank Menoufia University and the Higher Institute of Engineering and Technology (Tanta).

\section{REFERENCES}

(1) Shikhaliyev, N. Q.; Kuznetsov, M. L.; Maharramov, A. M.; Gurbanov, A. V.; Ahmadova, N. E.; Nenajdenko, V. G.; Mahmudov, K. T.; Pombeiro, A. J. L. Noncovalent interactions in the design of bisazo dyes. CrystEngComm 2019, 21, 5032-5038.

(2) Shahzad, D.; Saeed, A.; Larik, F. A.; Channar, P. A.; Abbas, Q.; Alajmi, M. F.; Arshad, M. I.; Erben, M. F.; Hassan, M.; Raza, H.; Seo, S.-Y.; El-Seedi, H. R. Novel C-2 symmetric molecules as $\alpha$-glucosidase and $\alpha$-amylase inhibitors: design, synthesis, kinetic evaluation, molecular docking and pharmacokinetics. Molecules 2019, 24, $1511-1527$.
(3) Shukla, H. M.; Shah, P. J.; Shah, A. R.; Solanki, Y. K.; Raj, D. S. Synthesis characterization and biological evalution of bis-azo dye ligands based coordination polymers. Chem. Sin. 2012, 3, 1280-1288.

(4) Patel, D. R.; Patel, B. M.; Patel, N. B.; Patel, K. C. Application of newly synthesized bisazo dichloro-s-triazinyl reactive dyes bearing 1,3,4-oxadiazole molecule. J. Saudi Chem. Soc. 2014, 18, 245-254.

(5) Kovalchukova, O. V.; Abdulilla Abbas, A. T. R.; Strashnova, S. B.; Strashnov, P. V. Tautomeric transformations and electronic structures of azopyrazolone dyes and their metal complexes. Rev. Inorg. Chem. 2018, 38, 87-101.

(6) Peter, H. Metallized bisazo dyes, their preparation and use. US Patent 6,302,949,B1, 2001,

(7) Omar, A. Z.; Mahmoud, M. N.; El-Sadany, S. K.; Hamed, E. A.; El-atawy, M. A. A combined experimental and DFT investigation of mono azo thiobarbituric acid based chalcone disperse dyes. Dyes Pigm. 2021, 185, 108887-108899.

(8) Aly, A. A.; Mourad, A.-F. E.; Hassan, A. A.; Mohamed, N. K.; Ali, B. A.; El-Sayed, M. M. Novel reaction products from thiobarbituric acid of biological interest. Arch. Pharm. 2004, 337, 133-139.

(9) Masoud, M. S.; Soayed, A. A.; Ali, A. E.; Sharsherh, O. K. Synthesis and characterization of new azopyrimidine complexes. $J$. Coord. Chem. 2003, 56, 725-742.

(10) Rathee, P.; Tonk, R. K.; Dalal, A.; Ruhil, M. K.; Kumar, A. Synthesis and application of thiobarbituric acid derivatives as antifungal agents. Cell. Mol. Biol. 2016, 62, 141.

(11) Al-Radadi, N. S.; Zayed, E. M.; Mohamed, G. G.; Abd El Salam, H. A. Synthesis, spectroscopic characterization, molecular docking, and evaluation of antibacterial potential of transition metal complexes obtained using triazole chelating ligand. J. Chem. 2020, 2020, 1-12. (12) Cheng, X.-X.; Hojaghani, S.; Hu, M.-L.; Hosaini Sadr, M.; Morsali, A. Sonochemical synthesis and characterization of new nanostructures cobalt(II) metal-organic complexes derived from the azo-couplingreaction of 4-amino benzoic acid with anthranilic acid, salicylaldehydeand 2-naphtol. Ultrason. Sonochem. 2017, 37, 614-622.

(13) Nagajyothi, P. C.; Pandurangan, M.; Kim, D. H.; Sreekanth, T. V. M.; Shim, J. Green synthesis of iron oxide nanoparticles and their catalytic and in vitro anticancer activities. J. Cluster Sci. 2017, 28, $245-257$.

(14) Gupta, V.; Chandra, N. Biosynthesis and antibacterial activity of metal oxide nanoparticles using Brassica oleracea subsp. botrytis (L.) leaves, an agricultural Waste. Proc. Natl. Acad. Sci. 2020, 90, $1093-1100$

(15) Izadiyan, Z.; Shameli, K.; Miyake, M.; Hara, H.; Mohamad, S. E. B.; Kalantari, K.; Taib, S. H. M.; Rasouli, E. Cytotoxicity assay of plant-mediated synthesizediron oxide nanoparticles using Juglans regia green husk extract. Arabian J. Chem. 2020, 13, 2011-2023.

(16) Halli, M. B.; Sumathi, R. B. Synthesis, physico-chemical investigations and biological screening of metal (II) complexes with Schiff base derived from naphthofuran-2-carbohydrazide and citral. Arabian J. Chem. 2017, 10, S1748-S1759.

(17) Abouzayed, F. I.; Emam, S. M.; Abouel-Enein, S. A. Synthesis, characterization and biological activity of nano-sized $\mathrm{Co}(\mathrm{II}), \mathrm{Ni}$ (II), $\mathrm{Cu}(\mathrm{II}), \mathrm{Pd}(\mathrm{II})$ and $\mathrm{Ru}(\mathrm{III})$ complexes of tetradentate hydrazine ligand. J. Mol. Struct. 2020, 1216, 128314.

(18) Mahmoud, W. H.; Refaat, A. M.; Mohamed, G. G. Nano Schiff base and its metal complexes: synthesis, characterization tools, biological applications and molecular docking studies. Egypt. J. Chem. 2020, 63, 2157-2176.

(19) Refat, M. S.; El-Korashy, S. A.; Ahmed, A. S. A convenient method for the preparation of barbituric and thiobarbituric acid transition metal complexes. Spectrochim. Acta, Part A 2008, 71, 10841094

(20) Sahoo, J.; Sahoo, S.; Kumar, P. S. Synthesis, characterization and solvatochromic effect of some azo based 2-thioxopyrimidine-4,-6dione analogues and their antimicrobial evaluation. Asian J. Chem. 2015, 27, 4145-4152.

(21) Mendez, E.; Cerda, M. F.; Gancheff, J. S.; Torres, J.; Kremer, C.; Castiglioni, J.; Kieninger, M.; Ventura, O. N. Tautomeric forms of 
2-thiobarbituric acid as studied in the solid, in polar solutions, and on gold nanoparticles. J. Phys. Chem. C 2007, 111, 3369-3383.

(22) Masoud, M. S.; Khalil, E. A.; Hindawy, A. M.; Ali, A. E.; Mohamed, E. F. Spectroscopic studies on some azo compounds and their cobalt, copper and nickel complexes. Spectrochim. Acta, Part A 2004, 60, 2807-2817.

(23) Abouel-Enein, S. A.; Emam, S. M.; Monir, E. Coordination modes of multidentate azodye ligand derived from 4,4'-methylenedianiline towards some transition metal ions: Synthesis, spectral characterization, thermal investigation and biological activity. Appl. Organomet. Chem. 2018, 32, 1-15.

(24) Seferoğlu, Z. A study on tautomeric equilibria of new hetarylazo-6-aminouracils. ARKIVOC 2009, 7, 42-57.

(25) Nassar, M. Y.; El-Shwiniy, W. H.; El-Sharkawy, A. M.; ElDesoky, S. I. Design and synthesis of new thiobarbituric acid metal complexes as potent protease inhibitors: spectral characterization, thermal analysis and DFT calculations. J. Iran. Chem. Soc. 2018, 15, 269-280.

(26) Emam, S. M.; Abouel-Enein, S. A.; Abdel-Satar, E. M. Structural characterization, thermal investigation and biological activity of metal complexes containing Schiff Base ligand (Z)-3-(1-((4,6-dimethyl- $1 \mathrm{H}-$ pyrazolo[3,4-b] pyridin-3-yl)imino)ethyl)-4-hydroxy-6-methyl-2Hpyran-2-one. Appl. Organomet. Chem. 2019, 33, No. e4847.

(27) Emam, S. M.; Abouel-Enein, S. A.; Abouzayed, F. I. Synthesis, spectral characterization, thermal studies and biological activity of (Z)-5-((1,5-dimethyl-3-oxo-2-phenyl-2,3-dihydro-1H-pyrazol-4-yl)diazenyl)-6-hydroxy-2-mercaptopyrimidin-4(3H)-one and its metal complexes. Appl. Organomet. Chem. 2017, 31, No. e4073.

(28) Ali, A. E.; Beltagy, D.; Elasala, G. S.; Kolkaila, S. A. Spectral and biological studies of some selected thiouracil, barbital and thiobarbituric acid complexes. J. Drug Des. Res. 2018, 5, 1071-1079.

(29) Alaghaz, A.-N. M. A.; Zayed, M. E.; Alharbi, S. A.; Ammar, R. A. A.; Chinnathambi, A. Synthesis, spectroscopic identification, thermal, potentiometric and antibacterial activity studies of 4amino-5-mercapto-S-triazole Schiffs base complexes. J. Mol. Struct. 2015, 1087, 60-67.

(30) Nakamoto, K. Infrared and Raman Spectra of Inorganic and Coordination Compounds. 5rd ed.; John Wiley \& Sons, Inc.: New York, 1986.

(31) Afsan, F.; Dalia, S.; Hossain, S.; Sarker, S.; E-Zahan, K. Synthesis, Spectral and Thermal Characterization of Selected Metal Complexes Containing Schiff Base Ligands with Antimicrobial Activities. Asian J. Chem. Sci. 2018, 4, 1-19.

(32) Al-Romaizan, A. N. Synthesis of some new barbituric and thiobarbituric acids bearing 1,2,4-Triazine moiety and their related systems as herbicidal agents. J. Chem. 2019, 2019, 1-6.

(33) Ghali, T. S.; Tomma, J. H. Synthesis and characterization of Indazol-3-one and thioxo pyrimidines derivatives from mono and twin chalcones. Iraq. J. Sci. 2017, 58, 2265-2277.

(34) Emam, S. M.; Abou EL-Enein, S. A.; Monir, E. Spectrochemical and thermal sudies for bivalent metal complexes of azodye ligand containing pyrimidine ring. Int. J. Eng. Res. Sci. Technol. 2017, 6, 354364.

(35) Patni, N.; Patni, M. Diazotization and coupling reactions of differently substituted aromatic amines and investigation of their solvatochromic behavior. Chem. Sin. 2016, 7, 93-100.

(36) Philip, S.; Thomas, P. S.; Mohanan, K. Synthesis, characterization, fluorescence imaging and cytotoxicity studies of a uracil-based azo derivative and its metal complexes. J. Chin. Chem. Soc. 2019, 66, $21-30$.

(37) Kyei, S. K.; Akarantaa, O.; Darko, G. Synthesis, characterization and antimicrobial activity of peanut skin extract-azo-compounds. Sci. Afric. 2020, 8, No. e00406.

(38) Cakmak, M.; Ozturk, I. I.; Banti, C. N.; Manoli, M.; Moushi, E.; Tasiopoulos, A. J.; Grześkiewicz, A. M.; Kubicki, M.; Hadjikakou, S. K. Bismuth(III) bromide-thioamide complexes: synthesis, characterization and cytotoxic properties. Main Group Met. Chem. 2018, 41, 143-154.
(39) Gup, R.; Giziroglu, E.; Kirkan, B. Synthesis and spectroscopic properties of new azo-dyes and azo-metal complexes derived from barbituric acid and aminoquinoline. Dyes Pigm. 2007, 73, 40-46.

(40) Emam, S. M.; Abouel-Enein, S. A. E.-T.; El-Seady, S. M. Coordination behavior of N-Donor Schiff base derived from 2Benzoylpyridine toward $\mathrm{Mn}(\mathrm{II}), \mathrm{Co}(\mathrm{II}), \mathrm{Ni}(\mathrm{II}), \mathrm{Cu}(\mathrm{II}), \mathrm{Zn}(\mathrm{II})$, $\mathrm{Pd}(\mathrm{II})$, and $\mathrm{Cr}$ (III) metal ions: synthesis, spectroscopic and thermal studies, and biological activity: physiochemical studies of transition metal complexes of 2-benzoylpyridine Schiff base. J. Chin. Chem. Soc. 2017, 64, 261-281.

(41) Worachartcheewan, A.; Pingaew, R.; Lekcharoen, D.; Prachayasittikul, S.; Ruchirawat, S.; Prachayasittikul, V. synthesis, antioxidant and antimicrobial activities of metal complexes of 2thiouracil-hydroxyquinoline derivatives. Lett. Drug Des. Discovery 2018, 15, 602 .

(42) Hadi, M. A.; Kareem, I. K. Synthesis and characterization of some transition metal complexes with new azo-Schiff base ligand 3,4bis (( (1E,2E)-2-((2-((4- ( (Z)-(3-Hydroxyphenyl)Diazenyl)Naphthalen-1-yl)amino)ethyl)imino)-1,2-diphenylethylidene)amino)phenyl)(phenyl)methanone. Egypt. J. Chem. 2020, 63, 301313.

(43) Mahmoud, W. H.; Omar, M. M.; Sayed, F. N. Synthesis, spectral characterization, thermal, anticancer and antimicrobial studies of bidentate azo dye metal complexes. J. Therm. Anal. Calorim. 2016, 124, 1071-1089.

(44) AbouEl-Enein, S. A.; Emam, S. M.; Wagdy, R. M.; Abouzayed, F. I. Spectral and thermal investigation of novel biologically active (N(1,5-dimethyl-3-oxo-2-phenyl-2,3-dihydro-1H-pyrazol-4-yl)-2-(1,5-dimethyl-3-oxo-2-phenyl-2,3-dihydro-1H-pyrazol-4-yl-amino)-2-oxo-cetimidic acid) ligand and its metal complexes. J. Mol. Struct. 2020, 1215,128230

(45) Masoud, M. S.; Abed, I. M.; El-zawawy, R. O. Structural studies and biological activity of thioarituric acid Complexes. J. Pharm. Med. Chem. 2018, 4, 55-65.

(46) Masoud, M. S.; El-Marghany, A.; Orabi, A.; Ali, A. E.; Sayed, R. Spectral, coordination and thermal properties of 5-arylidene thiobarbituric acids. Spectrochim. Acta, Part A 2013, 107, 179-187.

(47) Al-Hamdani, A. A. S.; Al-Khafaji, N. R.; Shaalan, N. Preparation, spectral, thermal and bio activity studies of azo dyes complexes. RJPBCS 2017, 8, 740-750.

(48) Yahya, W. I.; Mahdi, R. T.; Al-Hakeim, H. K. Synthesis, characterization of new chelate complexes derived from azo naphthresorcenol ligand. J. Pharma Sci. Res. 2018, 10, 2841-2845.

(49) Al-Saif, F. A. Spectroscopic, Molar conductance and biocidal studies of $\mathrm{Pt}(\mathrm{IV}), \mathrm{Au}(\mathrm{III})$ and $\mathrm{Pd}(\mathrm{II})$ chelates of nitrogen and oxygen containing Schiff base derived from 4-aminoantipyrine and 2Furaldehyde. Int. J. Electrochem. Sci. 2013, 8, 10424-10445.

(50) Vimal Kumar, P. M.; Radhakrishnan, P. K. Synthesis, spectral and X-ray structural studies of a NO donor Schiff base ligand and its $\mathrm{Ni}(\mathrm{II})$ complexes. Inorg. Chim. Acta 2011, 375, 84-92.

(51) Shaker, S. A.; Khaledi, H.; Cheah, S.-C.; Ali, H. M. New $\mathrm{Mn}(\mathrm{II}), \mathrm{Ni}(\mathrm{II}), \mathrm{Cd}(\mathrm{II}), \mathrm{Pb}(\mathrm{II})$ complexes with 2-methylbenzimidazole and other ligands. Synthesis, spectroscopic characterization, crystal structure, magnetic susceptibility and biological activity studies. Arabian J. Chem. 2016, 9, S1943-S1950.

(52) El-Ghamry, H. A.; Fathalla, S. K.; Gaber, M. Synthesis, structural characterization and molecular modelling of bidentate azo dye metal complexes: DNA interaction to antimicrobial and anticancer activities. Appl. Organomet. Chem. 2018, 32, No. e4136.

(53) El-Boraey, H. A.; Emam, S. M.; Tolan, D. A.; El-Nahas, A. M. Structural studies and anticancer activity of a novel (N6O6) macrocyclic ligand and its $\mathrm{Cu}(\mathrm{II})$ complexes. Spectrochim. Acta, Part A 2011, 78, 360-370.

(54) El-Saied, F. A.; Al-Hakimi, A. N.; Wahba, M. A.; Shakdofa, M. M. E. Preparation, characterization and antimicrobial activities of N'((3-(hydroxyimino) butan-2-ylidene)-2 (phenylamino) acetohydrazide and its metal complexes. Egypt. J. Chem. 2017, 60, 1-24.

(55) Mahmoud, W. H.; Deghadi, R. G.; Mohamed, G. G. Preparation, geometric structure, molecular docking thermal and 
spectroscopic characterization of novel Schiff base ligand and its metal chelates. J. Therm. Anal. Calorim. 2017, 127, 2149-2171.

(56) Kavitha, N.; Anantha Lakshmi, P. V. Synthesis, characterization and thermogravimetric analysis of $\mathrm{Co}(\mathrm{II}), \mathrm{Ni}$ (II), $\mathrm{Cu}$ (II) and $\mathrm{Zn}$ (II) complexes supported by ONNO tetradentate Schiff base ligand derived from hydrazino benzoxazine. J. Saudi Chem. Soc. 2017, 21, S457-S466.

(57) Ahmadi, R. A.; Amani, S. Synthesis, spectroscopy, thermal analysis, magnetic properties and biological activity studies of $\mathrm{Cu}$ (II) and $\mathrm{Co}(\mathrm{II})$ complexes with Schiff Base dye ligands. Molecules 2012, 17, 6434-6448.

(58) KarapJnar, E.; Gubbuk, I. H.; Taner, B.; Deveci, P.; Ozcan, E. Thermal degradation behaviour of $\mathrm{Ni}$ (II) complex of 3,4-methylenedioxaphenylaminoglyoxime. J. Chem. 2013, 2013, 548067.

(59) Piloyan, G. O.; Pyabonikar, T. D.; Novikova, C. S. Determination of Activation Energies of Chemical Reactions by Differential Thermal Analysis. Nature 1966, 212, 1229-1304.

(60) Gaber, M.; El-Ghamry, H. A.; Fathalla, S. K.; Mansour, M. A. Synthesis, spectroscopic, thermal and molecular modeling studies of $\mathrm{Zn}^{2+}, \mathrm{Cd}^{2+}$ and $\mathrm{UO}_{2}{ }^{2+}$ complexes of Schiff bases containing triazole moiety, antimicrobial, anticancer, antioxidant and DNA binding studies. Mater. Sci. Eng. 2018, 83, 78-89.

(61) Bal, S.; Bal, S. S. Cobalt(II) and Manganese(II) complexes of novel Schiff bases, synthesis, charcterization and thermal, antimicrobial, electronic, and catalytic features. Adv. Chem. 2014, 2014, 1-12.

(62) AbouEl-Enein, S. A.; Emam, S. M.; Polis, M. W.; Emara, E. M. Synthesis and characterization of some metal complexes derived from azo compounds of 4,4-methelnedianiline and antipyrine: Evaluation of their biological activity on some land snails. J. Mol. Struct. 2015, 1099, 567-578.

(63) Althobiti, H. A.; Zabin, S. A. New Schiff bases of 2-(quinolin-8yloxy)acetohydrazide and their $\mathrm{Cu}(\mathrm{II})$, and $\mathrm{Zn}$ (II) metal complexes: their in vitro antimicrobial potentials and in silico physicochemical and pharmacokinetics properties. Open Chem. 2020, 18, 591-607.

(64) Kurt, Y.; Deniz, N. G. Iron(III), nickel(II) and zinc(II) complexes based on acetophenone-S-methyl-thiosemicarbazone: synthesis, characterization, thermogravimetry, and a structural study. J. Coord. Chem. 2015, 68, 4070-4081.

(65) Handoyo Sugiyarto, K.; Kusumawardani, C.; Sutrisno, H.; Wahyu Arif Wibowo, M. Structural analysis of powdered Manganese(II) of 1,10-Phenanthroline (phen) as ligand and trifluoroacetate (TFA) as counter anion. OJCHEG 2018, 34, 735-742.

(66) Prasad, S.; Agarwal, R. K. Nickel(II) Complexes of hydrazone of isoniazid and their magneto-spectral, electrochemical, thermal and antimicrobial investigations. Res. Lett. Inorg. Chem. 2008, 2008, 350921.

(67) Alothman, A. A.; Albaqami, M. D. Nano-sized $\mathrm{Cu}(\mathrm{II})$ and $\mathrm{Zn}$ (II) complexes and their use as aprecursor for synthesis of $\mathrm{CuO}$ and $\mathrm{ZnO}$ nanoparticles: Astudy on their sonochemical synthesis, characterization,and DNA-binding/cleavage, anticancer, and antimicrobialactivities. Appl. Organomet. Chem. 2020, 34, No. e5827.

(68) Wang, C.-C.; Jing, H.-P.; Zhang, Y.-Q.; Wang, P.; Gao, S.-J. Three coordination compounds of cobalt with organic carboxylic acids and 1,10-phenanthroline as ligands: syntheses, structures and photocatalytic properties. Transition Met. Chem. 2015, 40, 573-584.

(69) Zaki, Z. M.; Abbas, S. M.; Dessoukii, H. A.; Awes, H. S.; Mahmoud, R. Synthesis, structural elucidation and antimicrobial activities of 5-(3-nitrophenyllazo)-6-aminouracil and its complexes with some transition metal ions. Mater. Sci. Eng. 2018, 464, 012009.

(70) Emam, S. M.; El Sayed, I. E. T.; Ayad, M. I.; Hathout, H. M. R. Synthesis, characterization and anticancer activity of new Schiff bases bearing neocryptolepine. J. Mol. Struct. 2017, 1146, 600-619.

(71) Jain, R.; Mishra, A. P. Microwave assisted synthesis, spectroscopic, thermal and antimicrobial studies of some transition metal complexes of Schiff base ligands containing thiazole moiety. Jordan J. Chem. 2012, 7, 9-21.

(72) Aruna, K.; Bootwala, S.; Tariq, M.; Fernandes, C.; Somasundaran, S. Synthesis, characterization, thermal and kinetic studies of lanthanum(III) and thorium(III) and dioxouranium(VI) chelates with multidentate ligand and its in vitro antibacterial analysis. IJPSR 2014, 5, 400-409.

(73) El-Gammal, O. A.; El-Asmy, A. A. Synthesis and spectral characterization of 1-(aminoformyl- N -phenylform)-4- ethylthiosemicarbazide and its metal complexes. J. Coord. Chem. 2008, 61, 22962306.

(74) El-Kholy, D. E.; Mostafa, M. M. Synthesis, characterization and biological studies of $\mathrm{Cu}^{2+}, \mathrm{Ni}^{2+}, \mathrm{Cd}^{2+}$ and $\mathrm{Pt}^{4+}$ complexes derived from 3-(3H-1,2,4-triazole-4-(5H)-ylimino)butane-2-one-oxime (L). J. Transition Met. Complexes 2020, 3, 1-15.

(75) Maravalli, P. B.; Goudar, T. R. Thermal and spectral studies of 3-N-methyl-morpholino-4-amino-5-mercapto1,2,4-triazole and 3-Nmethyl-piperidino-4-amino-5-mercapto-1,2,4-triazole complexes of cobalt(II), nickel(II) and copper(II). Thermochim. Acta 1999, 325, $35-41$.

(76) AlZamil, N. O. Synthesis, DFT calculation, DNA-binding, antimicrobial, cytotoxic and molecular docking studies on new complexes $\mathrm{VO}(\mathrm{II}), \mathrm{Fe}(\mathrm{III}), \mathrm{Co}(\mathrm{II}), \mathrm{Ni}(\mathrm{II})$ and $\mathrm{Cu}(\mathrm{II})$ of pyridine Schiff base ligand. Mater. Res. Express 2020, 7, 065401

(77) Borase, J. N.; Mahale, R. G.; Rajput, S. S.; Shirsath, D. S. Design, synthesis and biological evaluation of heterocyclic methyl substituted pyridine Schif base transition metal complexes. SN Appl. Sci. 2021, 3, 197.

(78) Masoud, M. S.; El-Merghany, A.; Ramadan, A. M.; Abd ElKaway, M. Y. Thermal studies of some purine compounds and their metal complexes. J. Therm. Anal. Calorim. 2010, 101, 839-847.

(79) Munde, A.; Jagdale, A.; Jadhav, S.; Chondhekar, T. Synthesis, characterization and thermal study of some transition metal complexes of an asymmetrical tetradentate Schiff base ligand. J. Serb. Chem. Soc. 2010, 75, 349-359.

(80) Sikha, T. S.; Indrasenan, P. Thermal decomposition kinetics of some aniline complexes of zinc group metals. Indian J. Chem., Sect. A: Inorg., Bio-inorg., Phys., Theor. Anal. Chem. 2004, 43, 1393-1402.

(81) El-Sonbati, A. Z.; Diab, M. A.; El-Bindary, A. A.; Mohamed, G. G.; Morgan, S. M. Thermal, spectroscopic studies and hydrogen bonding in supramolecular assembly of azo rhodanine complexes. Inorg. Chim. Acta 2015, 430, 96-107.

(82) Chellaian, J. D.; S.S, S. R. Co(II), Ni(II), Cu(II), and Zn(II) complexes of 4-aminoantipyrine-derived Schiff base. Synthesis, structural elucidation, thermal, biological studies and photocatalytic activity. J. Heterocycl. Chem. 2021, 58, 928-941.

(83) Kafi-Ahmadi, L.; Shirmohammadzadeh, L. Synthesis of Co(II) and $\mathrm{Cr}$ (III) salicylidenic Schiff base complexes derived from thiourea as precursors for nano-sized $\mathrm{Co}_{3} \mathrm{O}_{4}$ and $\mathrm{Cr}_{2} \mathrm{O}_{3}$ and their catalytic, antibacterial properties. J. Nanostruct. Chem. 2017, 7, 179-190.

(84) El-Saied, F. A.; Salem, T. A.; Shakdofa, M. M. E.; Al-Hakimi, A. N.; Radwan, A. S. Antitumor activity of synthesized and characterized $\mathrm{Cu}(\mathrm{II}), \mathrm{Ni}(\mathrm{II})$ and $\mathrm{Co}(\mathrm{II})$ complexes of hydrazone-oxime ligands derived from 3-(hydroxyimino) butan-2-one. Beni-Seuf Univ. J. Appl. Sci. 2018, 7, 420-429.

(85) Fathima, S. S. A.; Meeran, M. M. S.; Nagarajan, E. R. Synthesis, characterization and biological evaluation of novel $2,2^{\prime}-((1,2-$ diphenylethane-1,2-diylidene)bis(azanylylidene)) bis(pyridin-3ol)and metal complexes: molecular docking and in silico ADMET profile. Struct. Chem. 2020, 31, 521-539.

(86) Bhunia, A.; Manna, S.; Mistri, S.; Paul, A.; Manne, R. K.; Santra, M. K.; Bertolasi, V.; Chandra Manna, S. Synthesis, characterization, TDDFT calculation and biological activity of tetradentate ligand based square pyramidal $\mathrm{Cu}(\mathrm{II})$ complexes. RSC Adv. 2015, 5, 6772767737.

(87) Hasan, A.; Morshed, M.; Memic, A.; Hassan, S.; Webster, T.; Marei, H. Nanoparticles in tissue engineering: applications, challenges and prospects. Int. J. Nanomed. 2018, 13, 5637-5655.

(88) Nikolova, M. P.; Chavali, M. S. Metal Oxide Nanoparticles as Biomedical Materials. Biomimetics 2020, 5, 27.

(89) Zayed, E. M.; Hindy, A. M. M.; Mohamed, G. G. Coordination behaviour, molecular docking, density functional theory calculations and biological activity studies of some transition metal complexes of bis-Schiff base ligand. Appl. Organomet. Chem. 2019, 33, No. e4525. 
(90) Mumit, M. A.; Pal, T. K.; Alam, Md. A.; Islam, Md. A.; Paul, S.; Sheikh, Md. C. DFT studies on vibrational and electronic spectra, HOMO-LUMO, MEP, HOMA, NBO and molecular docking analysis of benzyl-3-N-(2,4,5-trimethoxyphenylmethylene)hydrazinecarbodithioate. J. Mol. Struct. 2020, 1220, 128715.

(91) Sherif, O. E.; Abdel-Kader, N. S. DFT calculations, spectroscopic studies, thermal analysis and biological activity of supramolecular Schiff base complexes. Arabian J. Chem. 2018, 11, 700-713.

(92) Madkour, L. H.; Elshamy, I. H. Experimental and computational studies on the inhibition performances of benzimidazole and its derivatives for the corrosion of copper in nitric acid. Int. J. Ind. Chem. 2016, 7, 195-221.

(93) Elmacı, G.; Duyar, H.; Aydıner, B.; Yahaya, I.; Seferoğlu, N.; Şahin, E.; Çelik, S. P.; Açık, L.; Seferoğlu, Z. Novel benzildihydrazone based Schiff bases: Syntheses, characterization, thermal properties, theoretical DFT calculations and biological activity studies. J. Mol. Struct. 2019, 1184, 271-280.

(94) Rakha, T. H.; El-Gammal, O. A.; Metwally, H. M.; Abu ElReash, G. M. Synthesis, characterization, DFT and biological studies of (Z)-NÆ-(2-oxoindolin-3-ylidene)picolinohydrazide and its $\mathrm{Co}(\mathrm{II})$, $\mathrm{Ni}(\mathrm{II})$ and $\mathrm{Cu}(\mathrm{II})$ complexes. J. Mol. Struct. 2014, 1062, 96-109.

(95) Sanatkar, T. H.; Khorshidi, A.; Janczak, J. Dinuclear Zn(II) and tetranuclear $\mathrm{Co}$ (II) complexes of a tetradentate $\mathrm{N}_{2} \mathrm{O}_{2}$ Schiff base ligand: Synthesis, crystal structure, characterization, DFT studies, cytotoxicity evaluation, and catalytic activity toward benzyl alcohol oxidation. Appl. Organomet. Chem. 2020, 34, No. e5493.

(96) Abbaz, T.; Bendjeddou, A.; Villemin, D. A quantum chemical study of dendralene and radialene tetrathiafulvalene analogues. J. Sci. Eng. Res. 2018, 5, 140-149.

(97) Bassett, J.; Denney, R. C.; Jeffery, G. H.; Mendham, J. Vogel's Textbook, 4rd ed.; Longman Group: London, 1978.

(98) El-Enein, S. A. A.; Ali, A. M.; Abdel-Monem, Y. K.; Senna, M. H.; Madkour, M. Novel lanthanide(III) 4-methylbenzoylhydrazide complexes as precursors for lanthanide oxide nanophotocatalysts. RSC Adv. 2019, 9, 42010-42019.

(99) Gomha, S. M.; Riyadh, S. M.; Mahmmoud, E. A.; Elaasser, M. M. Synthesis and anticancer activities of thiazoles, 1,3-thiazines and thiazolidine using chitosan-grafted-poly(vinylpyridine) as basic catalyst. Heterocycles 2015, 91, 1227-1243.

(100) Yen, G. C.; Duh, P. D. Scavenging effect of methanolic extracts of peanut hulls on free radical and active oxygen species. J. Agric. Food Chem. 1994, 42, 629-632. 